\title{
Analysis and Mathematical Model for Restitution of Voltage Using Dynamic Voltage Restorer
}

\author{
C. Gopinath, ${ }^{1}$ C. Yaashuwanth, ${ }^{2}$ R. Ramesh, ${ }^{1}$ J. R. Maglin, ${ }^{1}$ and T. Ajith Bosco Raj ${ }^{1}$ \\ ${ }^{1}$ Department of Electrical and Electronics Engineering, Anna University, Chennai 600 025, India \\ ${ }^{2}$ Department of Information Technology, SRM University, Chennai 603 203, India \\ Correspondence should be addressed to C. Gopinath; gopime2002@gmail.com
}

Received 10 July 2013; Revised 17 January 2014; Accepted 6 February 2014; Published 24 April 2014

Academic Editor: Claudio R. Fuerte-Esquivel

Copyright (c) 2014 C. Gopinath et al. This is an open access article distributed under the Creative Commons Attribution License, which permits unrestricted use, distribution, and reproduction in any medium, provided the original work is properly cited.

\begin{abstract}
Voltage sag and swell have a major concern in the distribution systems. In order to mitigate the voltage sag and swell, a custom power device called dynamic voltage restorer (DVR) is used. The proposed system is a polymer electrolyte membrane (PEM) fuel cell based DVR. The energy from the fuel cell is stored in the super capacitor to restitute the voltage. In this proposed DVR, Z-source inverter is used instead of traditional inverter because of buck-boost and shoot through capability. The simulation is performed using three controller topologies: PI controller, synchronous reference frame controller and fuzzy controller and the results are verified using Matlab-Simulink environment.
\end{abstract}

\section{Introduction}

Recently series type voltage compensators are used to solve the voltage quality problems. Voltage sags and swells were the most frequent disturbances in the industrial sites. Voltage sags become disruptive, when the RMS (root mean square) magnitude dropped lower than $90 \%$ of the nominal voltage. Usually, there is significant phase unbalance than the balanced faults [1]. Dynamic voltage restorers (DVR) is an effective and economic way to compensate for voltage sags and swells $[2,3]$.

The voltage sags as defined by IEEE is "a decrease in RMS voltage or current at the power frequency for durations from 0.5 cycles to 1 minute, reported as the remaining voltage." Typical values are between 0.1 p.u. and 0.9 p.u., and fault clearing times range from three to thirty cycles depending on the fault current magnitude and the type of overcurrent detection and interruption [1-3]. DVR is used in low and medium voltage distribution network to protect sensitive load from sudden voltage sag or swell $[4,5]$. Pulse width modulation inverter is used to vary amplitude and phase angle of injected voltages, thus allowing control of real and reactive power exchange between distributed system and load [6]. For proper voltage sag compensation, it is necessary to derive suitable and fast control scheme for inverter switching [7, 8]. A fuel cell converts chemical energy into electric energy by electrochemical conversion. In this system, electric energy is generated as long as fuel is supplied continuously. It can also be considered a generating system similar to conventional generating systems [9].

Fuel cells produce DC output voltages. Polymer electrolyte membrane (PEM) fuel cells are attractive because they are modular, capable, and environmentally friendly. PEM operating temperature is $60-100^{\circ} \mathrm{C}$ and efficiency is $50-60 \%$. The control circuit monitors the utility and the fuel cell status continuously $[9,10]$. The traditional inverters are voltage source inverter (VSI) which consists of a diode rectifier, dc link, and inverter bridge. In order to improve the power factor, either an ac inductor or dc inductor is normally used. The VSI is a buck converter and can only produce an ac voltage limited by the $\mathrm{dc}$ link voltage. Because of this nature, VSI is characterized by relatively low efficiency because of switching losses and considerable EMI generation. Since the switches are used in the main circuit, each is traditionally composed of power transistors and antiparallel diode. It provides bidirectional current flow and unidirectional voltage blocking capability. Thus, inverter presents negligible switching losses and EMI generation at the line frequency. 


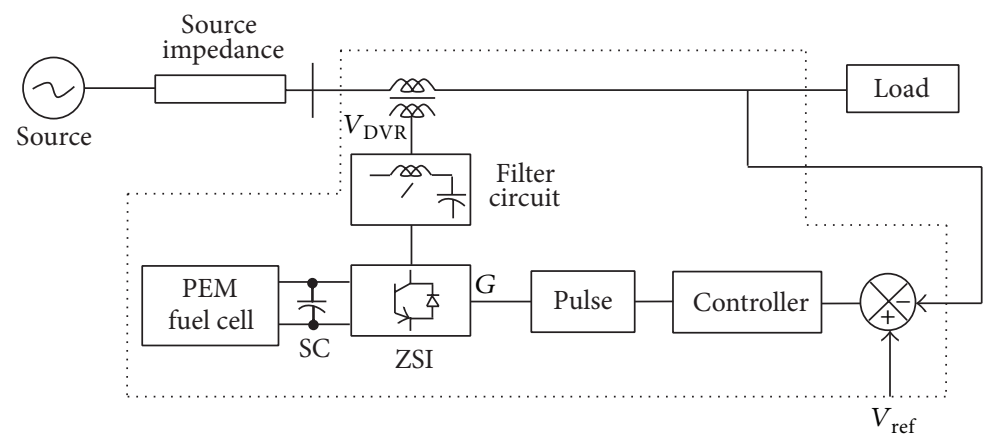

FIGURE 1: PEM fuel cell based DVR.

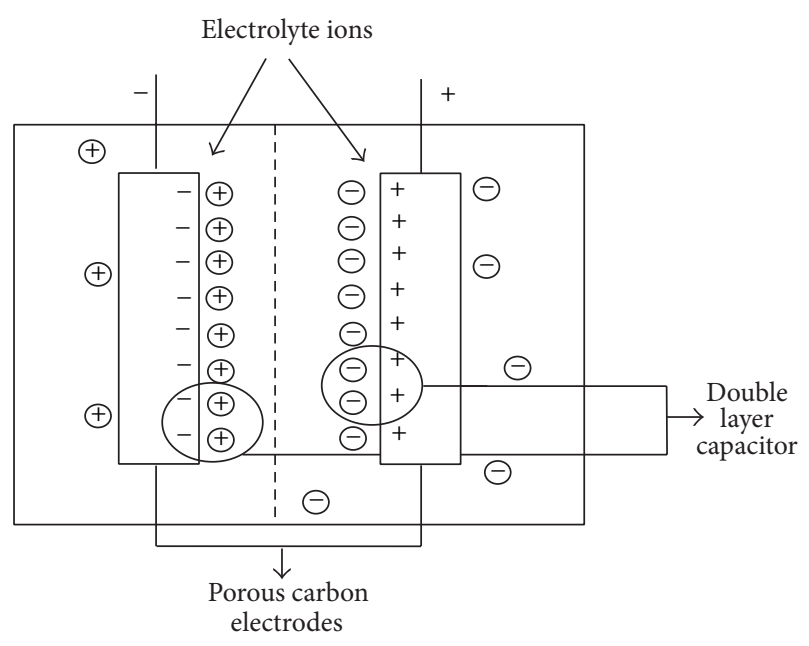

FIGURE 2: Supercapacitor.

The proposed Z-source inverter (ZSI) has the unique feature that it can boost/buck the output voltage by introducing shoot through operation mode, which is forbidden in traditional voltage source inverters [11]. With this feature, the ZSI provides a cheaper, simpler, buck-boost inversion by single power conversion stage, strong EMI immunity, and low harmonic distortion [12]. Super capacitor can store energy at a higher density than a normal capacitor $[13,14]$. When the amount of energy to be stored in a capacitor which increases the size of the capacitor, whereas super capacitor is compact. It has rapid charging and discharging capabilities, so that the efficiency of supercapacitor is higher than the conventional capacitor $[15,16]$. In this paper, dynamic voltage restorer uses fuel cell, super capacitor, and ZSI for the compensation of voltage sag and swell.

The PI controller converts the phase voltages into their respective $d-q$ components and generates a PWM signal based on the magnitude and angle of the $d-q$ components. The synchronous reference frame (SRF) technique is based on the instantaneous values of the supply voltage. In fuzzy logic, phase locked loop for each phase which tracks the phase of network voltage phasor generates a reference signal for each

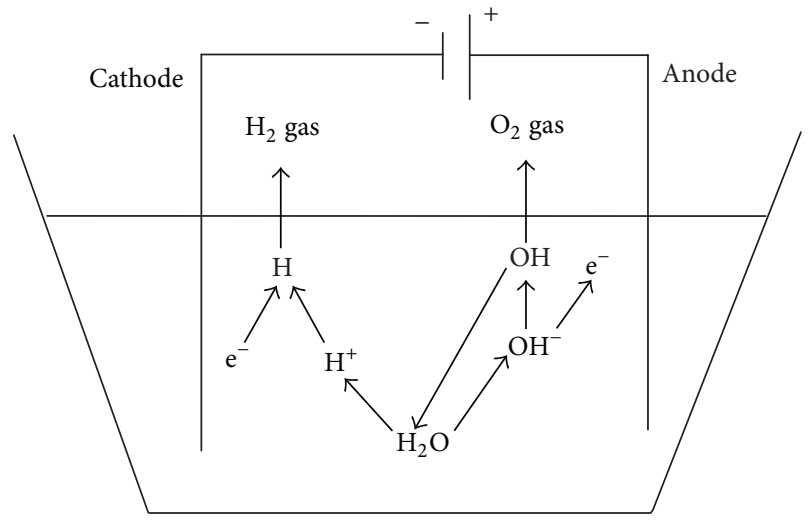

Figure 3: Fuel cell.

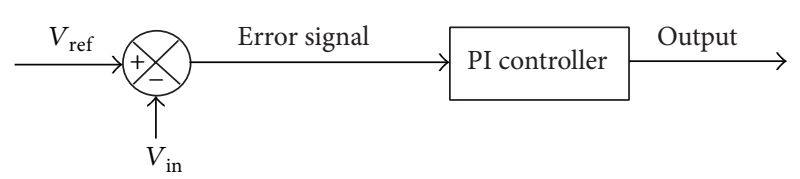

FIgURE 4: Control method.

phase, based on the fuzzy matrix. The supply voltage for each phase is converted to p.u and error is obtained.

\section{Proposed Method}

The most of the power quality problems are due to different fault conditions. These cause voltage sag and swell. Dynamic voltage restorers (DVR) can provide the cost effective solution to mitigate voltage sag by establishing the appropriate voltage quality level [8]. This compensation voltage is provided with the help of a fuel cell [13]. The overall block diagram of proposed fuel cell based compensation is given in Figure 1.

The DC voltage from the fuel cell is stored in a super capacitor. Super capacitors are new generation energy storage devices which store energy via charge separation at the electrode-electrolyte interface and they can withstand a large number of charge/discharge cycles without degradation. 

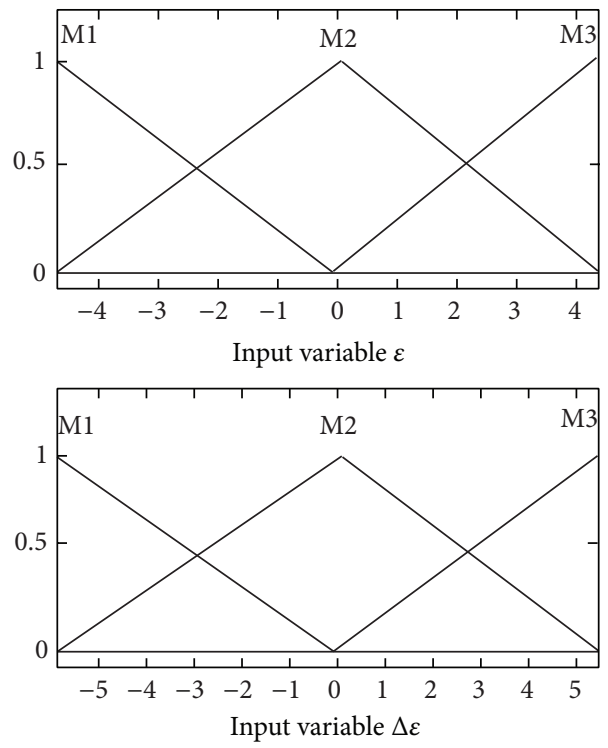

\begin{tabular}{|c|c|c|c|c|c|c|c|}
\hline$\varepsilon / \Delta \varepsilon$ & LP & MP & SP & S & SN & MN & LN \\
\hline LP & PB & PB & PB & PM & PM & PS & $Z$ \\
\hline MP & PB & PB & PM & PM & PS & $Z$ & NS \\
\hline SP & PB & PM & PM & PS & Z & NS & NM \\
\hline S & PM & PM & PS & Z & NS & NM & NM \\
\hline SN & PM & PS & Z & NS & NM & NM & NB \\
\hline MN & PS & $Z$ & NS & NM & NM & NB & NB \\
\hline LN & $Z$ & NS & NM & NM & NB & NB & NB \\
\hline
\end{tabular}

FIGURE 5: Fuzzy table and its membership function.

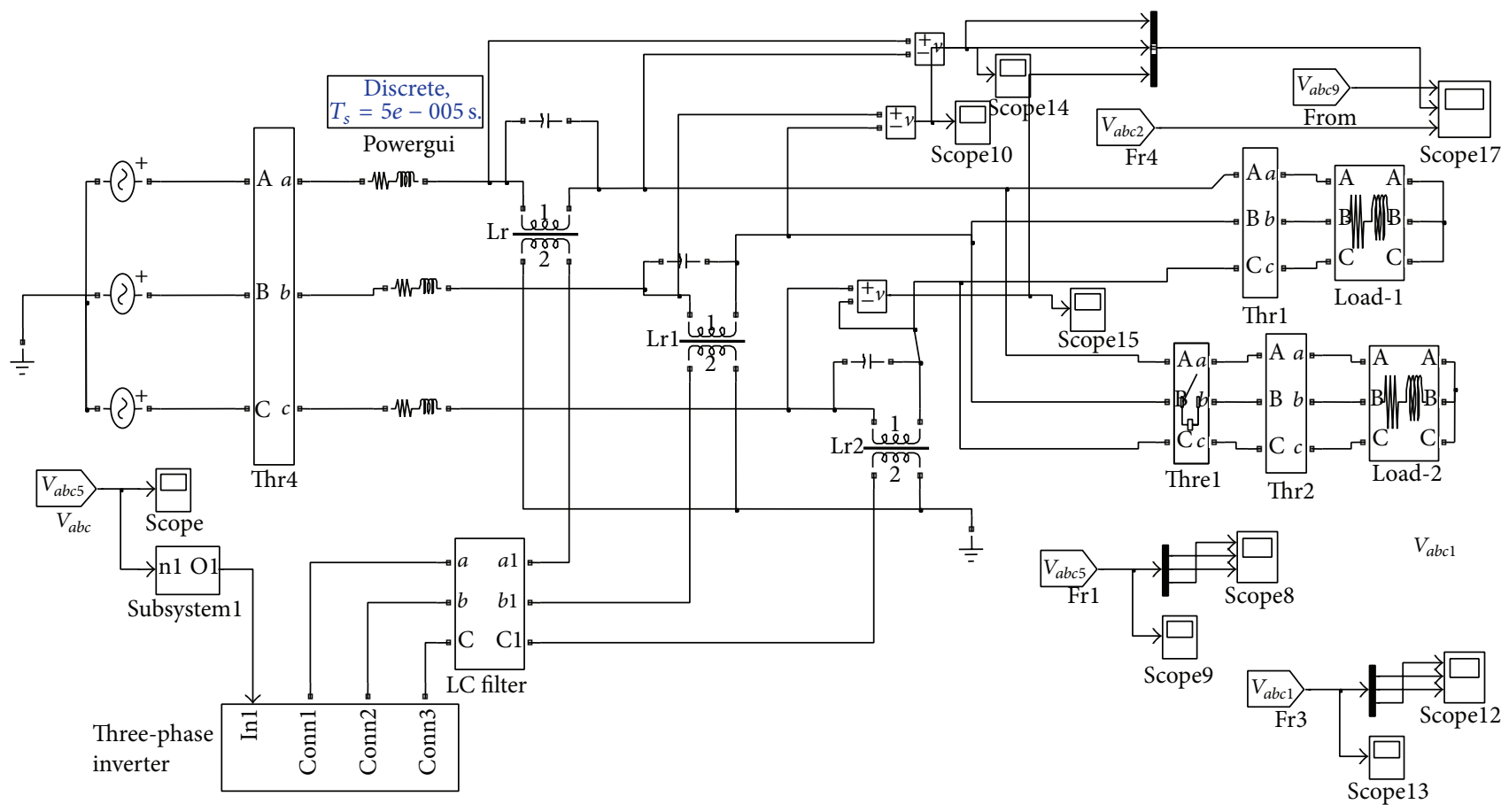

FIGURE 6: Simulink model for sag compensation.

The major advantages of super capacitors include higher capacitance density, higher charge-discharge cycles, reliable, long life and maintenance-free operation, environmentally safe, wide range of operating temperature, high power density, and good energy density [14]. The dc voltage is converted using an impedance source inverter. The proposed Z-source inverter has the unique features that it can boost/buck the output voltage by introducing shoot through operation mode, which is forbidden in traditional voltage source inverters.
With this unique feature, the Z-source inverter provides a cheaper, simpler, buck-boost inversion by single power conversion stage, strong EMI immunity, and low harmonic distortion.

2.1. Super Capacitor. Electrical double layer capacitors (EDLCS) are popularly known as ultracapacitor (UC) or super capacitor (SC) as shown in Figure 2. These devices are emerging very fast as green energy storage devices in the field 


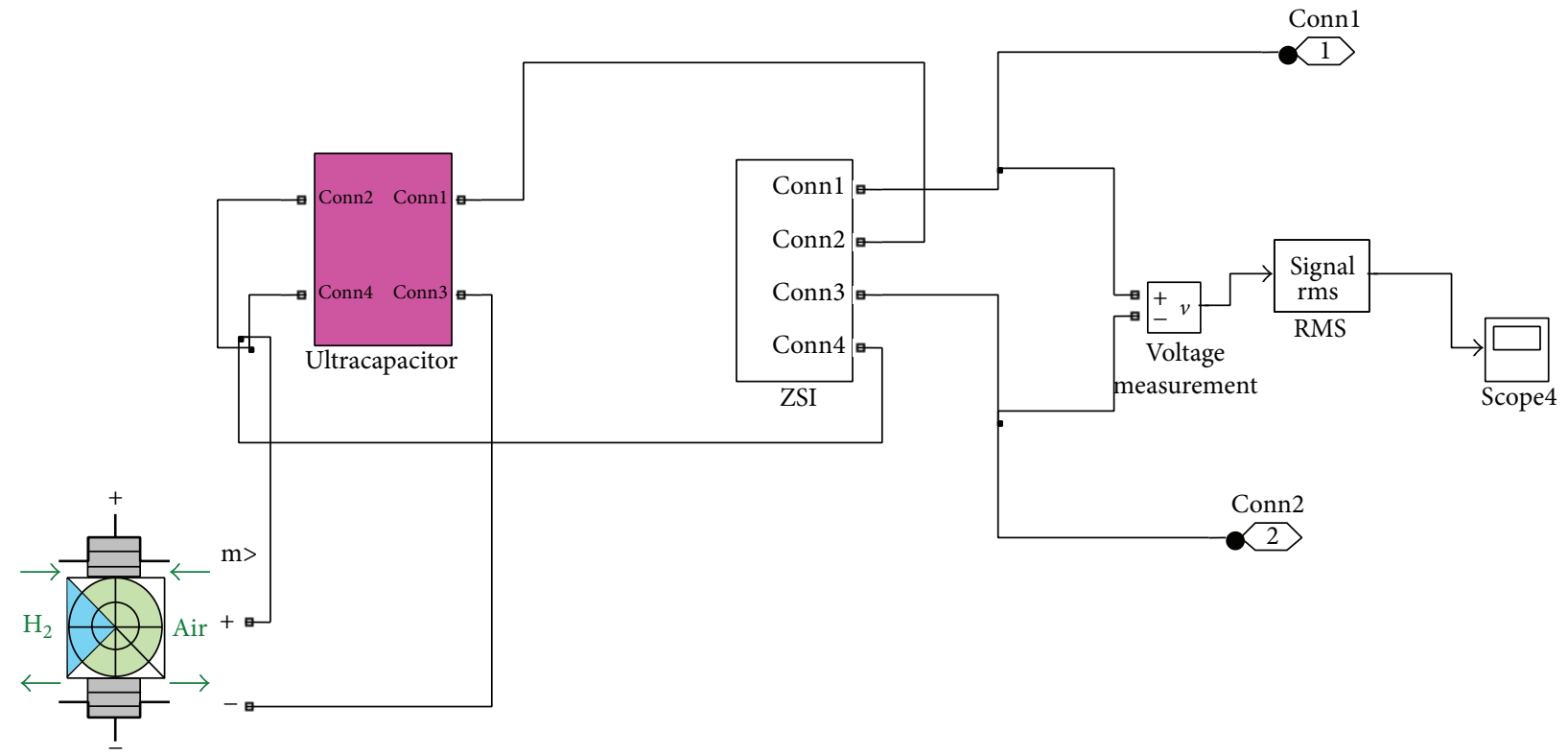

Fuel cell stack

Figure 7: Fuel cell subsystem.

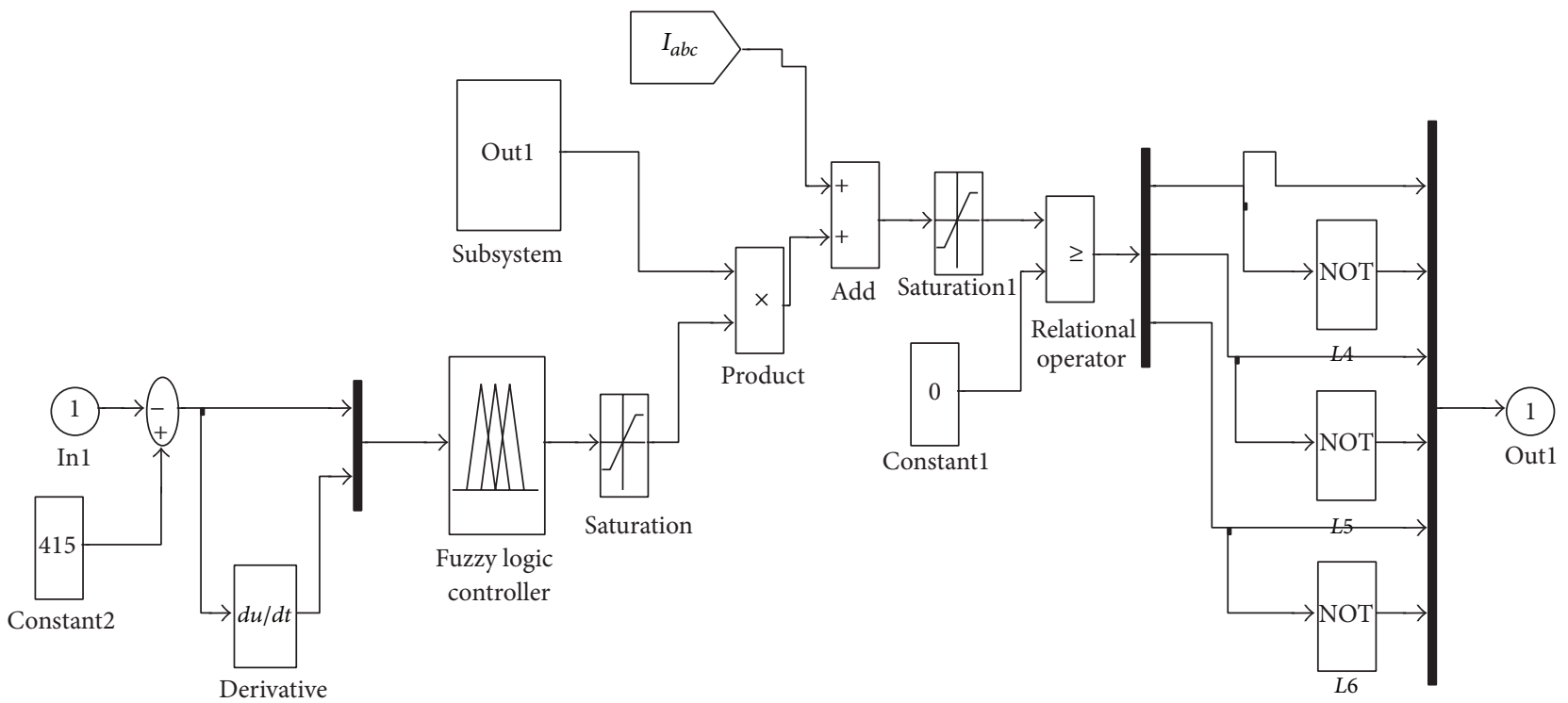

FIGURE 8: Fuzzy controller subsystem.

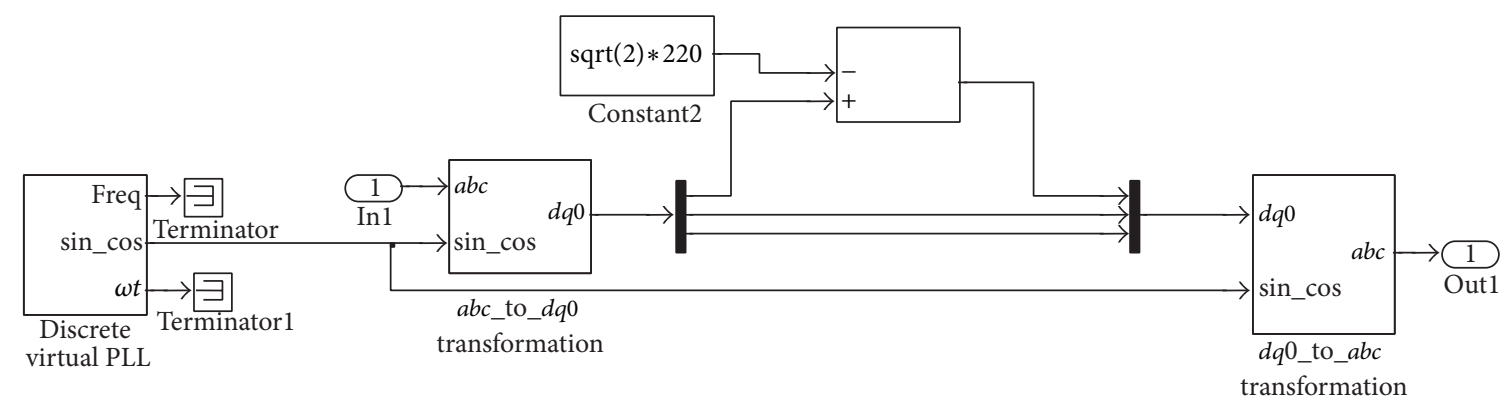

FIGURE 9: SRF subsystem. 


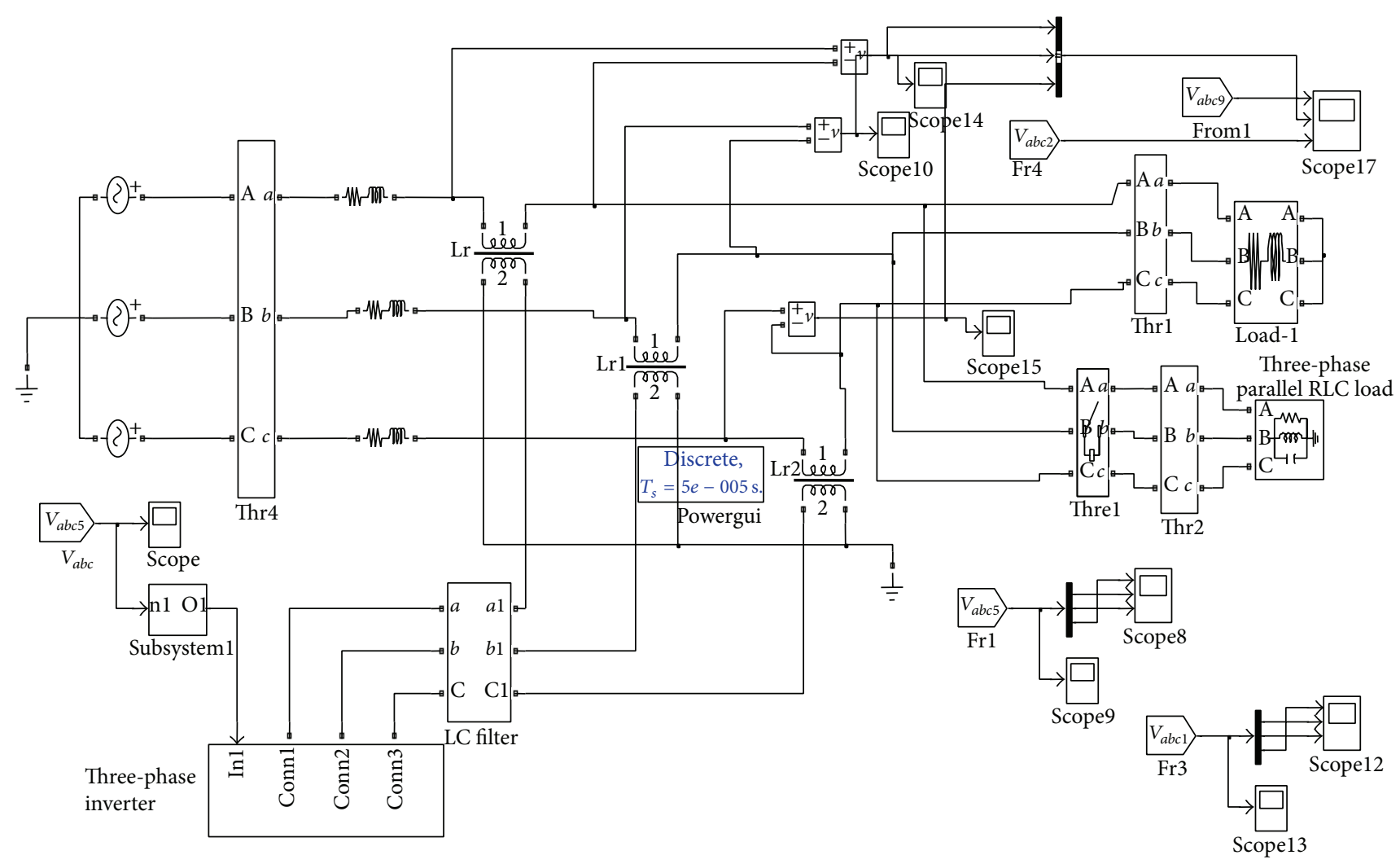

FIGURE 10: Simulink model for swell compensation (sudden removal of load).

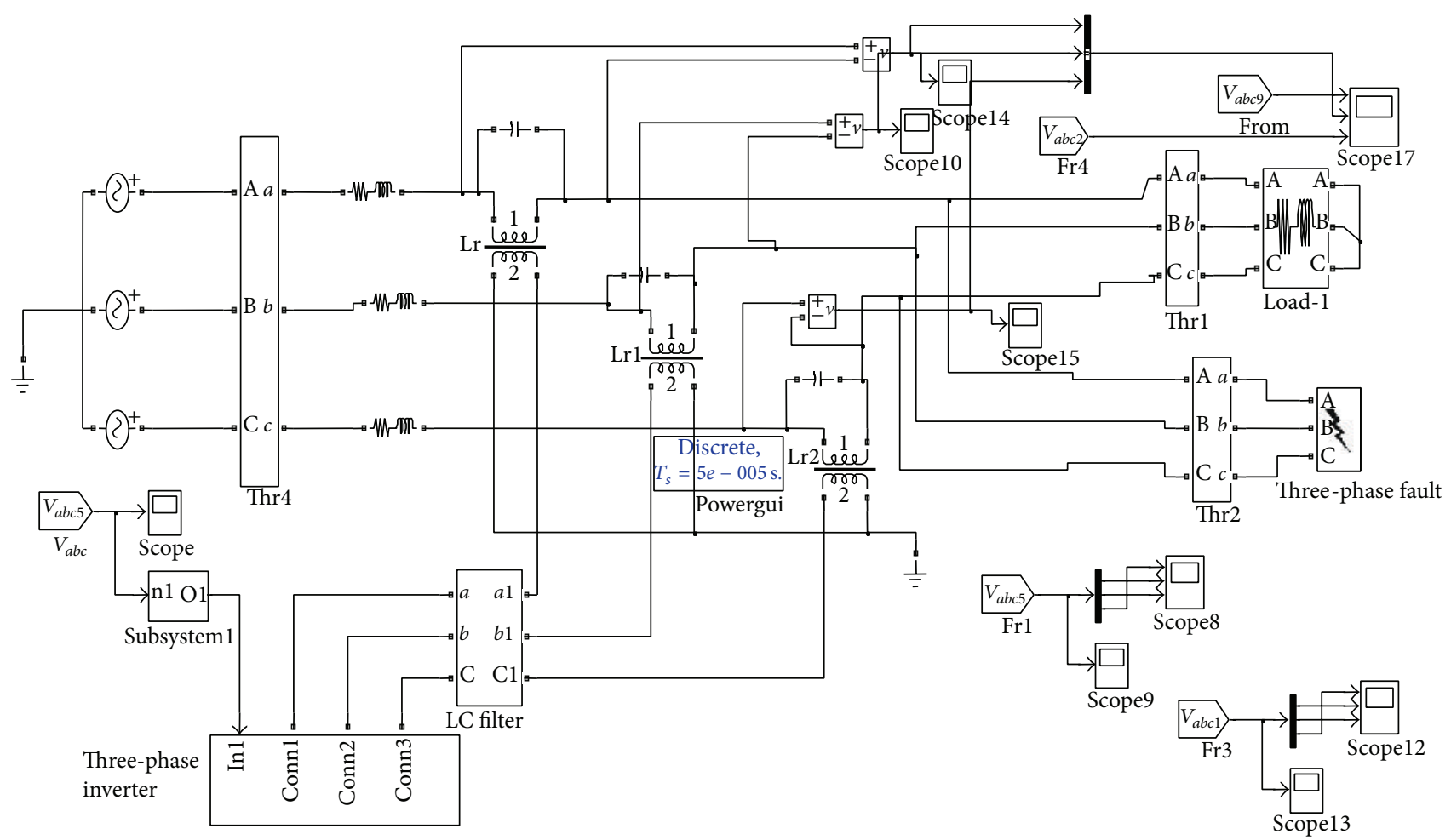

FIGURE 11: Simulink model for fault compensation. 


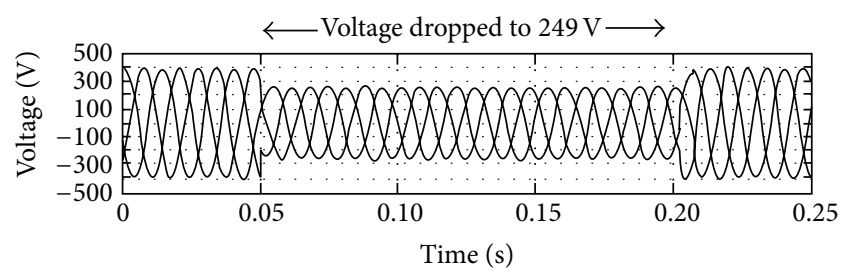

(a)

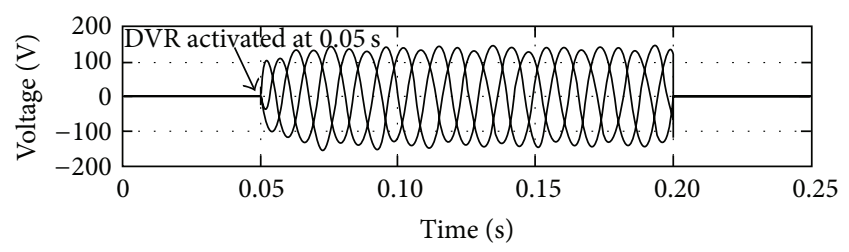

(b)

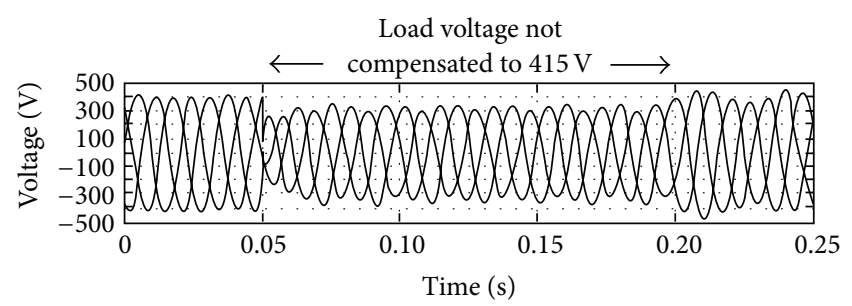

(c)

FIGURE 12: Sag compensation (40\%). (a) Three-phase sag voltage. (b) Three-phase DVR injected voltage. (c) Three-phase compensated load voltage.

of hybrid electrical vehicle, UPS system, along with FACTS devices in power system, drive applications, and utility applications [16]. Attractive features of ultracapacitor are its high capacitance, short duration peak power delivery capacity, that is, high power density, reduced space, environmentally safe, low power to weight ratio, and very long cycle life.

Various time domain models of ultracapacitor have been proposed by different authors to study its electrical behavior under various operating conditions [14-16]. The proposed method overcomes both these limitations and it is also verified by the simulation results. The purpose of UC detailed modeling is to predict its electrical and energetic behavior with high accuracy before implementation of UC in the actual system. The proposed model takes into account temperature effect and it fits in various operating conditions more accurately; the identification process is much simpler and it does not require very sophisticated instrumentation.

2.2. Fuel Cell. PEM stands for polymer electrolyte membrane or proton exchange membrane. Sometimes they are also called polymer membrane fuel cells or just membrane fuel cells. PEM fuel cells use a proton conductive polymer membrane as electrolyte. This technology has drawn the most attention because of its simplicity, viability, and quick startup and it has been used in almost any conceivable application from powering a cell phone to a locomotive. The structure

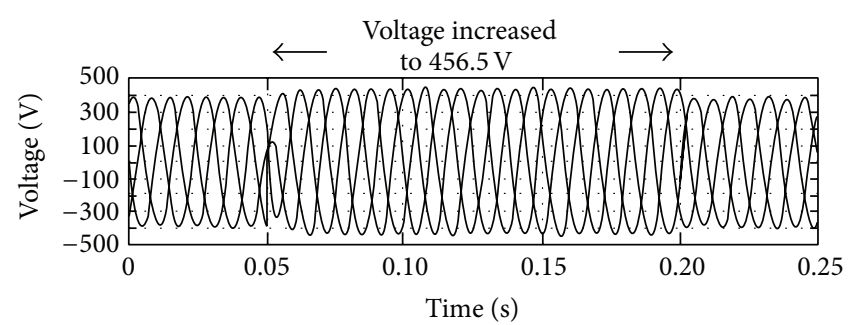

(a)

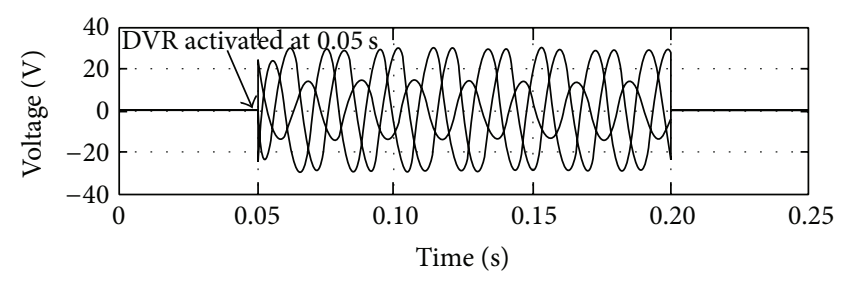

(b)

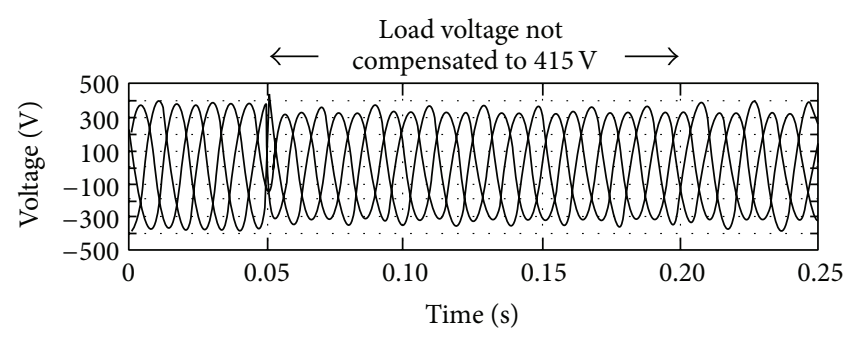

(c)

FIgURE 13: Swell compensation (10\%).

of fuel cell is shown in Figure 3. At the heart of a PEM fuel cell is a polymer membrane that has some unique capabilities. It is impermeable to gases but it conducts protons (proton exchange membrane). The membrane, which acts as the electrolyte, is squeezed between the two porous, electrically conductive electrodes. These electrodes are typically made out of carbon cloth or carbon fiber paper $[9,10]$. At the interface between the porous electrode and the polymer membrane there is a layer with catalyst particles, typically platinum supported on carbon. Electrochemical reactions occur at the surface of the catalyst at the interface between the electrolyte and the membrane.

Hydrogen which is fed on one side of the membrane splits into its primary constituents, protons and electrons. Each hydrogen atom consists of one electron and one proton. Protons travel through the membrane, while the electrons travel through electrically conductive electrodes, through current collectors and through the outside circuit where they perform useful work and return to the other side of the membrane. At the catalyst sites between the membrane and the other electrode they meet with the protons that went through the membrane and oxygen that is fed on that side of the membrane. Water is created in the electrochemical reaction and then pushed out of the cell with an excess flow of oxygen. The net result of these simultaneous reactions is current of electrons through an external circuit, direct electrical current. The hydrogen side is negative and is called 


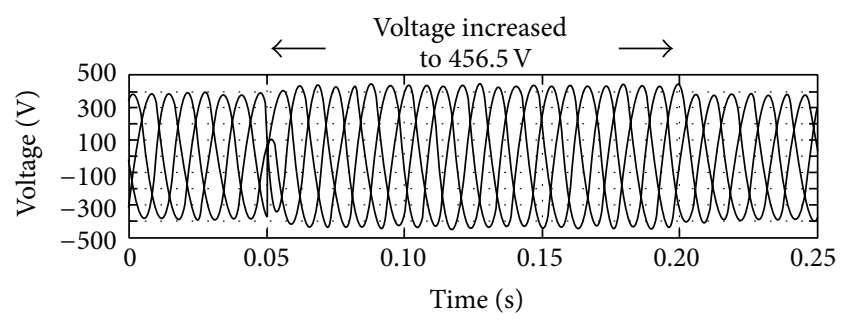

(a)

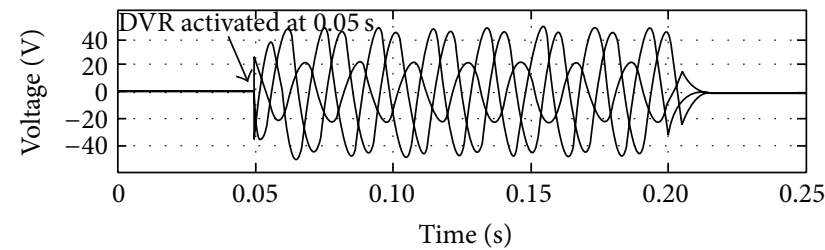

(b)

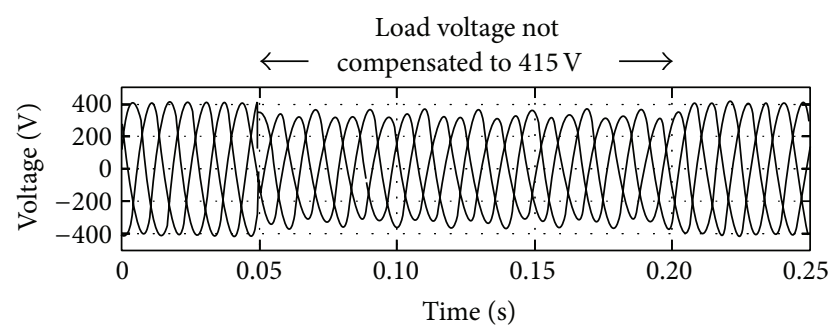

(c)

FIGURE 14: Swell compensation (removal of load).

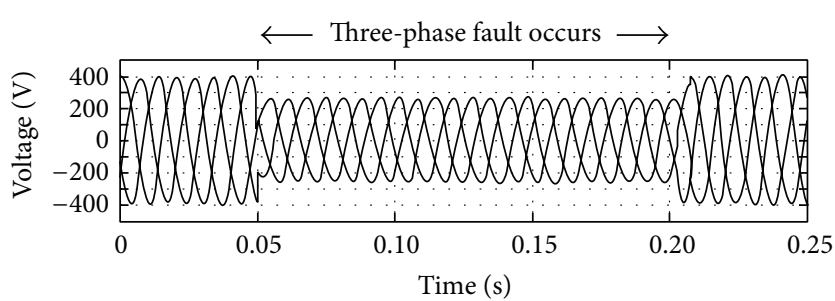

(a)

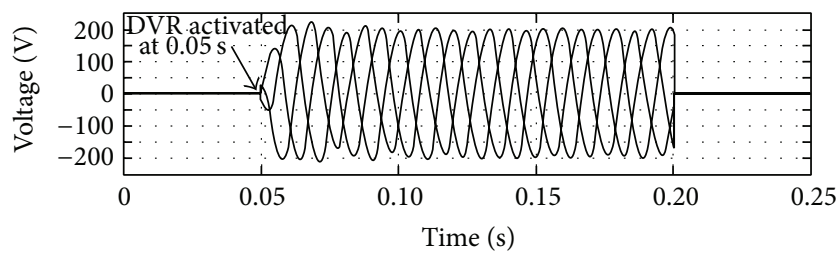

(b)

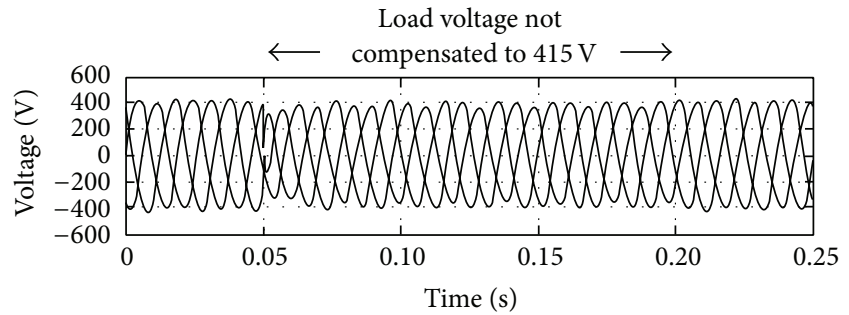

(c)

FIGURE 15: Three-phase fault sag compensation.

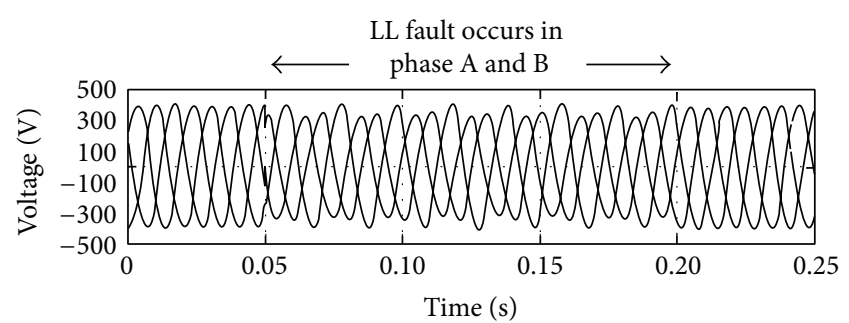

(a)

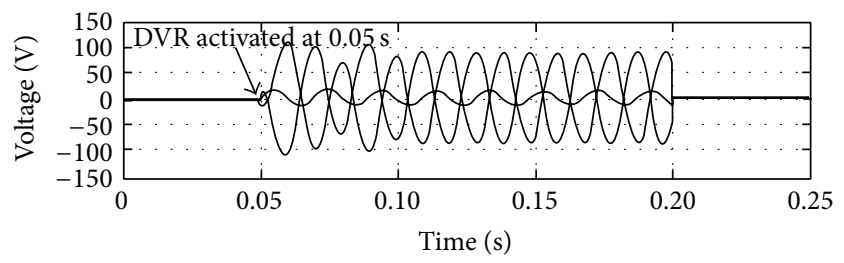

(b)

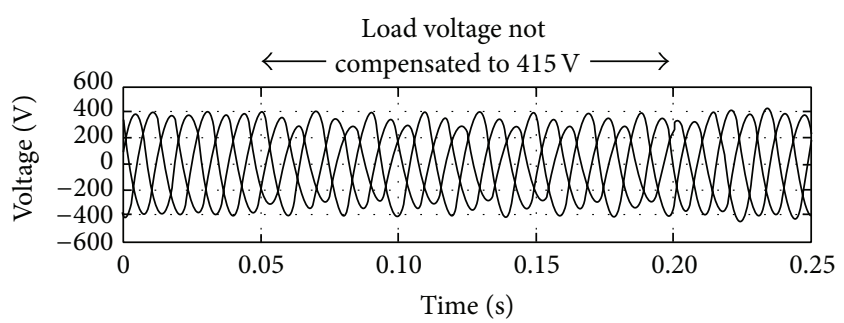

(c)

FiguRE 16: Line to Line fault sag compensation.

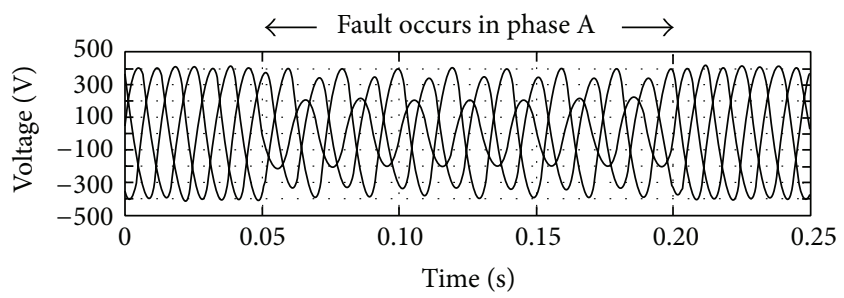

(a)

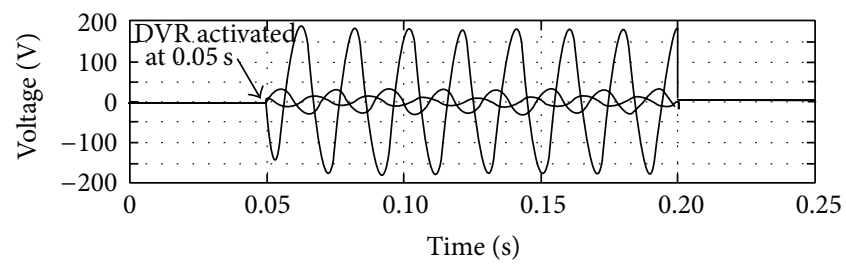

(b)

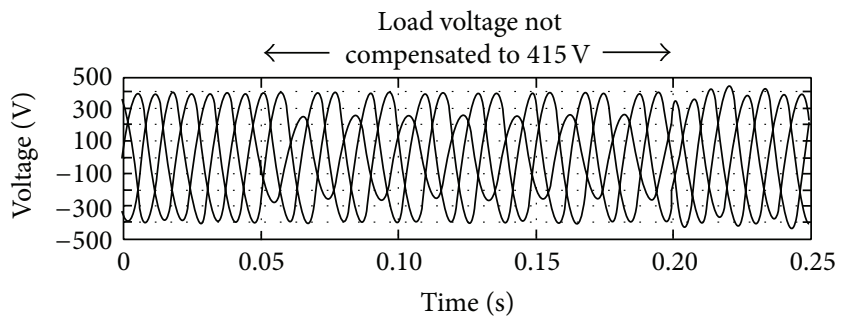

(c)

Figure 17: A single line to ground fault sag compensation. 


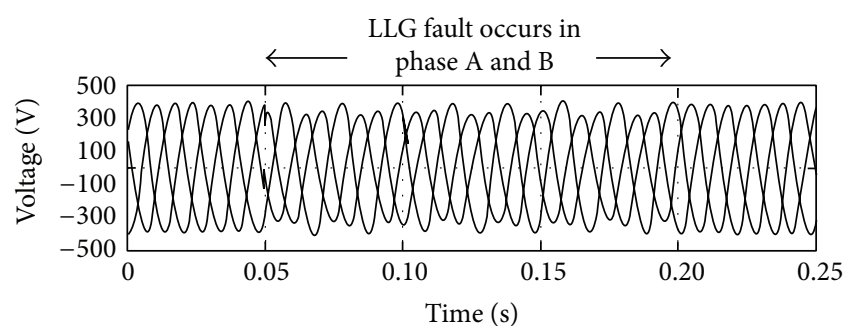

(a)

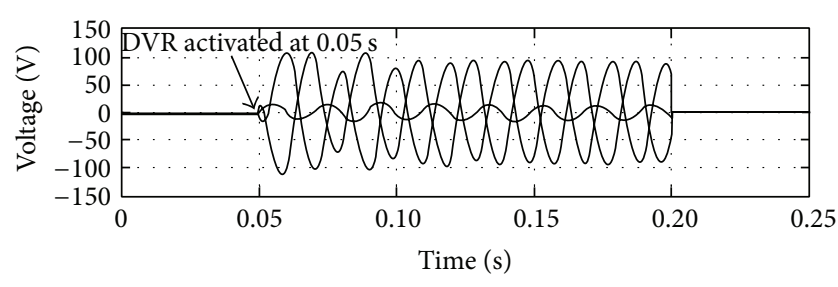

(b)

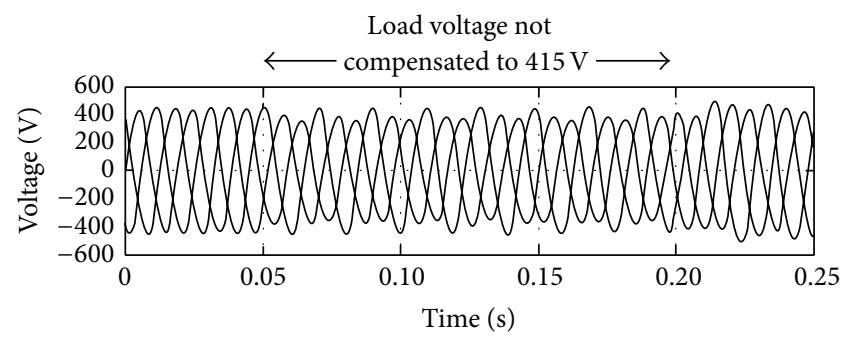

(c)

FIGURE 18: A double line to ground fault sag compensation.

the anode, while the oxygen side of the fuel cell is positive and is called the cathode [9].

The maximum amount of electrical energy generated in a fuel cell corresponds to Gibbs free energy [10]:

$$
W_{e 1}=-\Delta G
$$

Potential of fuel cell, $E$, is

$$
E=\frac{-\Delta G}{n F}
$$

where $n$ is the number of electrons and is equal to 2 and $F$ is Faraday's constant ( 96,485 coulombs/electron-mol). Then, potential can be calculated as

$$
E=\frac{-\Delta G}{n F}=\frac{2,37,340}{2 * 96,485}=1.23 \text { volts. }
$$

At $25^{\circ} \mathrm{C}$ and atmospheric pressure, the theoretical hydrogen/oxygen fuel cell potential is 1.23 Volts:

$$
\begin{aligned}
& \text { at cathode: } 2 \mathrm{H}_{2} \rightarrow 4 \mathrm{e}^{-}+4 \mathrm{H}^{+} \\
& \text {at anode: } \mathrm{O}^{2}+4 \mathrm{H}+4 \mathrm{e}^{-} \rightarrow 2 \mathrm{H}_{2} \mathrm{O} \\
& \text { overall: } 2 \mathrm{H}_{2}+\mathrm{O}_{2} \rightarrow 2 \mathrm{H}_{2} \mathrm{O}
\end{aligned}
$$

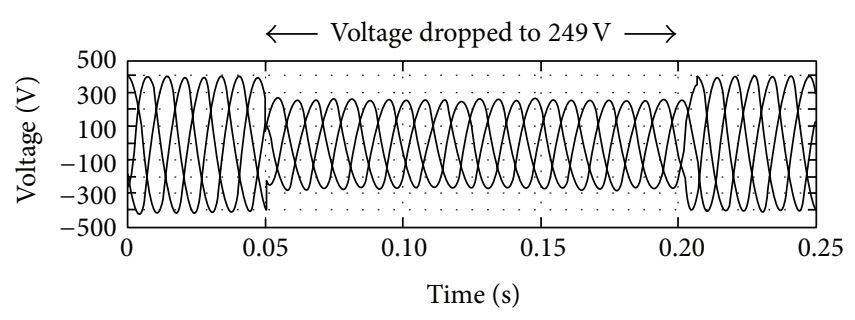

(a)

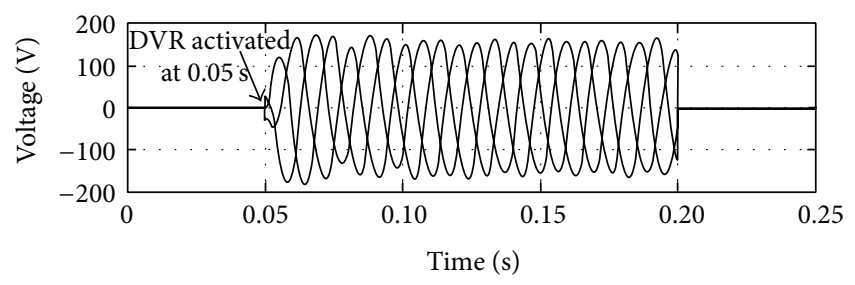

(b)

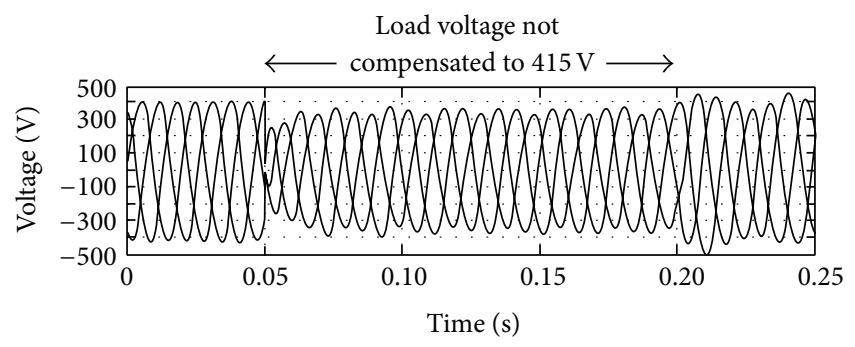

(c)

FIGURE 19: Sag compensation.

\section{Control Algorithm}

3.1. PI Controller. Sag occurs when there is increase in load or during the occurrence of fault and swell occurs when there is a sudden removal of load or due to addition of capacitor banks. This sag or swell in load voltage is sensed and its magnitude is compared with a reference voltage and the error signal is given to the PI controller as shown in Figure 4. The output of error detector is

$$
V_{\text {ref }}-V_{\text {in }} \text {, }
$$

where $V_{\text {ref }}$ is the reference voltage and $V_{\text {in }}$ is the load voltage.

The difference between load voltage, $V_{\text {in }}$, and reference voltage, $V_{\text {ref }}$, is supplied to the PI controller. From the controller, the voltage magnitude is taken as feedback. The IGBT inverter is triggered from the pulse generated by the PWM generator. The IGBTs are triggered depending on the firing angle, $\alpha$, which introduces additional lag or lead in the voltage [6]:

$$
\begin{aligned}
& V_{o}=\frac{1}{3}\left(V_{a}+V_{b}+V_{c}\right), \\
& {\left[\begin{array}{l}
V_{d} \\
V_{q}
\end{array}\right]=\frac{2}{3} R \omega t C\left[\begin{array}{l}
V_{a} \\
V_{b} \\
V_{c}
\end{array}\right] .}
\end{aligned}
$$




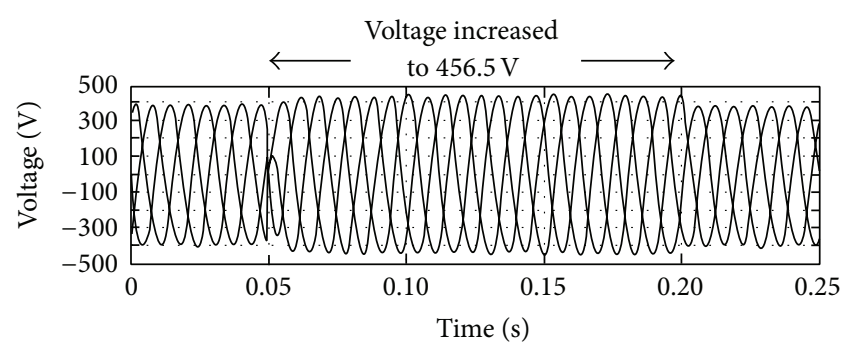

(a)

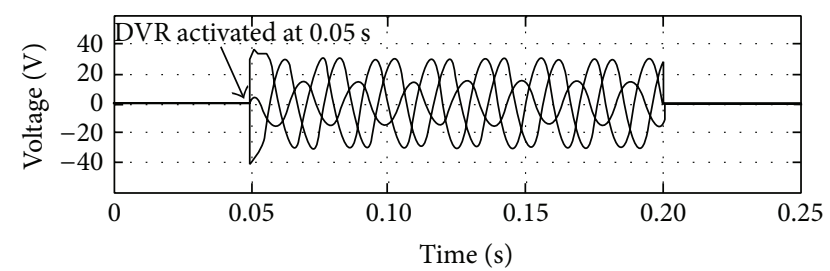

(b)

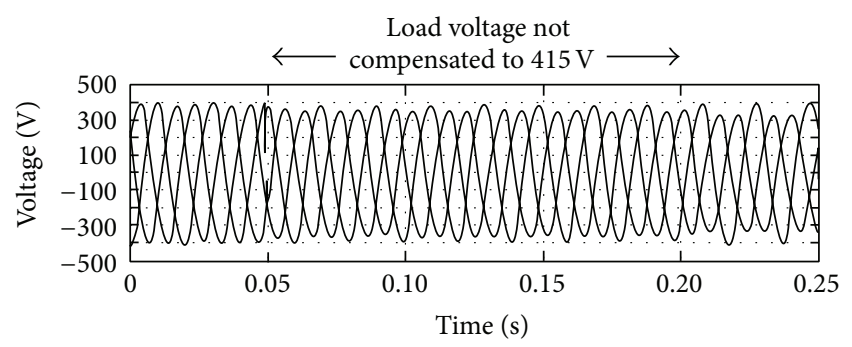

(c)

Figure 20: Swell compensation.

The supply side voltages, $V_{a}, V_{b}$, and $V_{c}$, are transformed into $d-q$ values of positive sequence:

$$
\begin{gathered}
C=\left[\begin{array}{ccc}
1 & -\frac{1}{2} & -\frac{1}{2} \\
0 & \sqrt{\frac{3}{2}} & -\sqrt{\frac{3}{2}}
\end{array}\right] \\
R(\omega t)=\left[\begin{array}{cc}
\cos \omega t & -\sin \omega t \\
\sin \omega t & \cos \omega t
\end{array}\right] .
\end{gathered}
$$

$R(\omega t)$ is a matrix that rotates by phase angle $\omega t$. Subscripts $d$ and $q$ represent the direct and quadrature axes. $V_{0}$ is the output voltage.

3.2. Synchronous Reference Frame Method. The general principle of DVR is that whenever the system detects a voltage sag/swell, the DVR should react as fast as possible and inject an ac voltage into the grid. It can be implemented using the synchronous reference frame (SRF) technique based on the instantaneous values of the supply voltage. The control algorithm produces a three-phase reference voltage to the PWM inverter that tries to maintain the load voltage at its reference value. The voltage sag/swell is detected by measuring the error between the supply voltage and the reference value. The reference component is set to a rated voltage. The SRF method can be used to compensate all types of voltage disturbances,

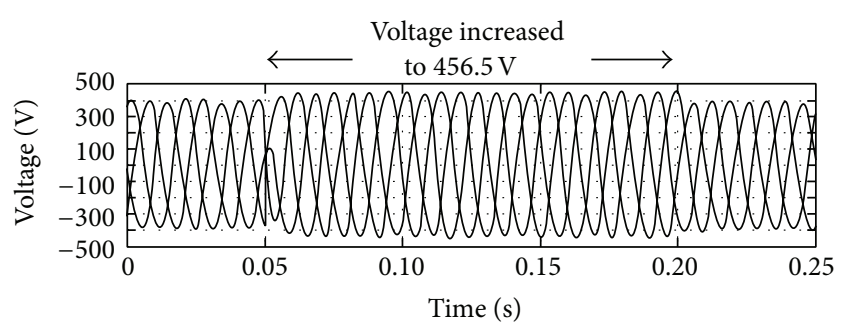

(a)

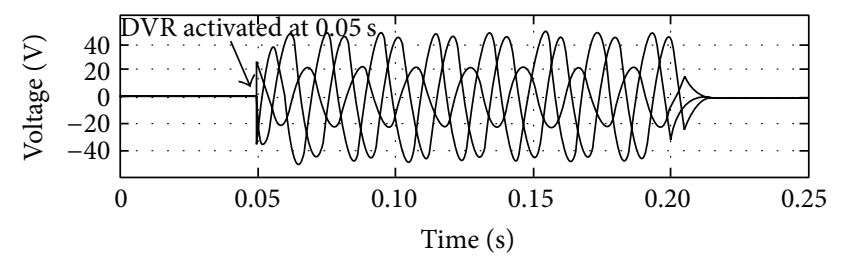

(b)

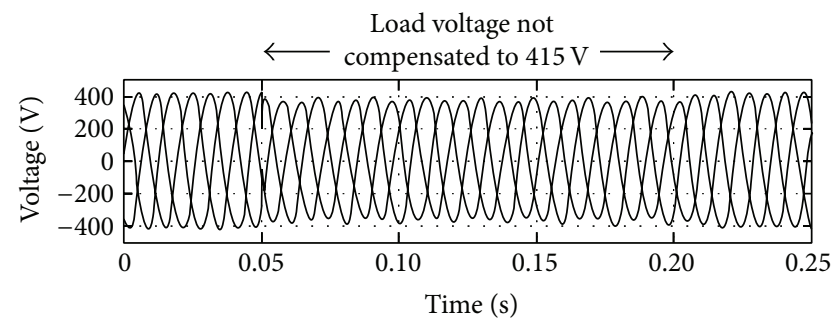

(c)

FIgURE 21: Swell compensation (removal of load).

voltage sag/swell, voltage unbalance, and harmonic voltage. The difference between the reference voltage and the supply voltage is applied to the ZSI to produce the load rated voltage, with the help of pulse width modulation (PWM) through the PI controller:

$$
\begin{aligned}
V_{d}=\frac{2}{3} & {\left[V_{a} \times \sin (\omega t)+V_{b}\right.} \\
& \left.\quad \times \sin \left(\omega t-\frac{2 \phi}{3}\right)+V_{c} \times \sin \left(\omega t+\frac{2 \phi}{3}\right)\right] \\
V_{q}=\frac{2}{3} & {\left[V_{a} \times \cos (\omega t)+V_{b}\right.} \\
& \left.\times \cos \left(\omega t-\frac{2 \phi}{3}\right)+V_{c} \times \cos \left(\omega t+\frac{2 \phi}{3}\right)\right] \\
V_{0}=\frac{1}{3} & {\left[V_{a}+V_{b}+V_{c}\right], }
\end{aligned}
$$

where $\omega=$ rotation speed $(\mathrm{rad} / \mathrm{s})$ of the rotating frame. We have

$$
\begin{aligned}
& V_{a}=\left[V_{d} \times \sin (\omega t)+V_{q} \times \cos (\omega t)+V_{0}\right] \\
& V_{b}=\left[V_{d} \times \sin \left(\omega t-\frac{2 \phi}{3}\right)+V_{q} \times \cos \left(\omega t-\frac{2 \phi}{3}\right)+V_{0}\right] \\
& V_{c}=\left[V_{d} \times \sin \left(\omega t+\frac{2 \phi}{3}\right)+V_{q} \times \cos \left(\omega t+\frac{2 \phi}{3}\right)+V_{0}\right] .
\end{aligned}
$$




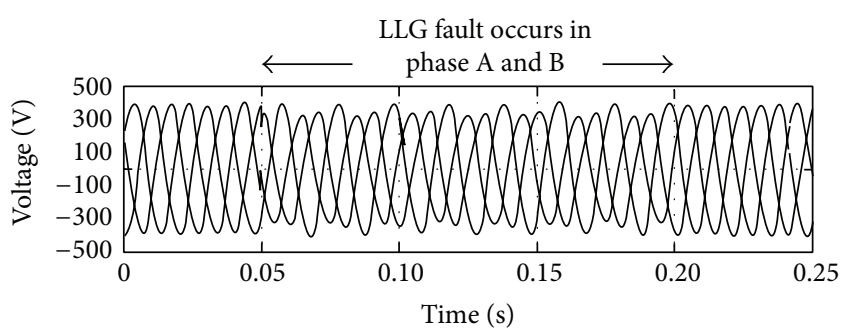

(a)

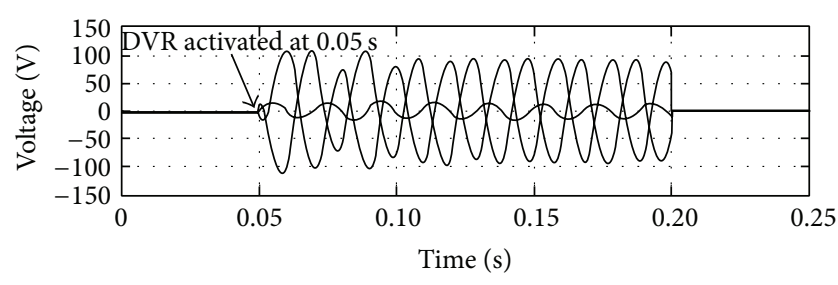

(b)

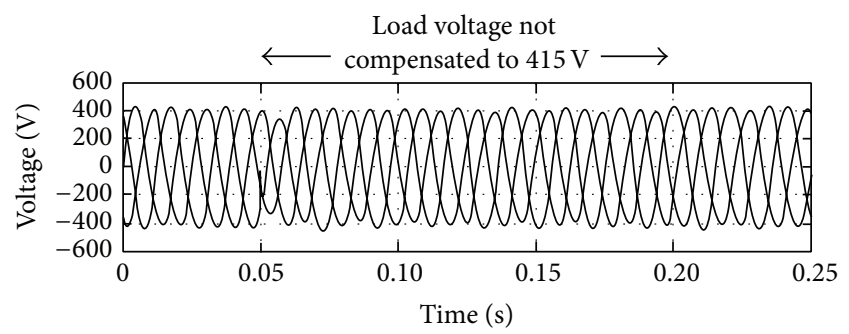

(c)

FIgURE 22: A double line to ground fault sag compensation.

3.3. Fuzzy Logic Algorithm. PI controller is the most frequently used controller in DVRs. But one disadvantage of this PI controller is its inability to work well under a wider range of operating conditions. So, as a solution fuzzy controller is proposed. The fuzzy table and its membership function are shown in Figure 5. In this method, PLL for each phase tracks the phase of network voltage phasor and generates a reference signal with magnitude of unit to supply frequency for each phase. The supply voltage for each phase is converted to pu and error is obtained from the difference of reference PLL generated signal and actual supply voltage converted to pu. Error and error rate are the inputs for the FL controller. Output of the FL controller is fed to the PWM generator to produce switching pulses for ZSI. The desired response from DVR-PLL system is quite different from other applications. This is because the phase of the supply voltage prior to the sag is generally preferred and if the PLL reacts quickly to changes in the phase during sag, the post-sag phase may be used. Therefore, the DVR would not be able to compensate for the phase jump. Conventionally, once sag is detected, the target phase of the voltage reference is fixed to the pre-sag phase to ensure that if the reference is correctly tracked, then the load voltage phase will remain unaffected. Through a suitable choice of the time constant of the PLL, the DVR restores the instantaneous voltage waveform in the sensitive load side to the same phase and magnitude as the initial pre-sag voltage.

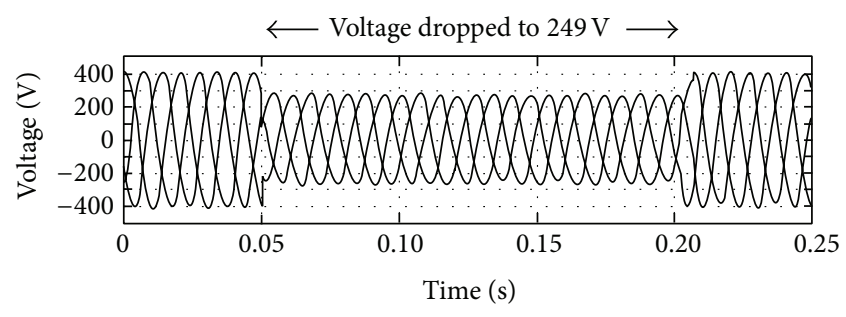

(a)

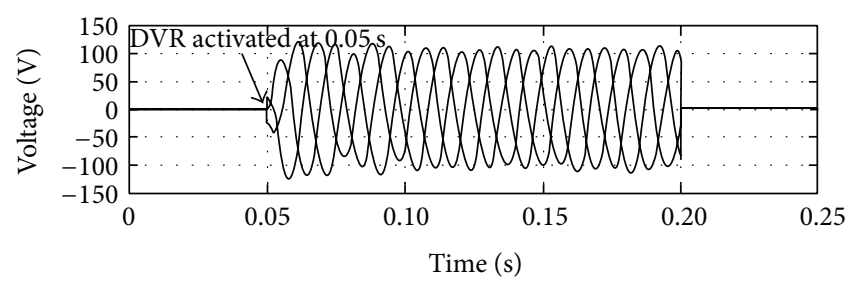

(b)

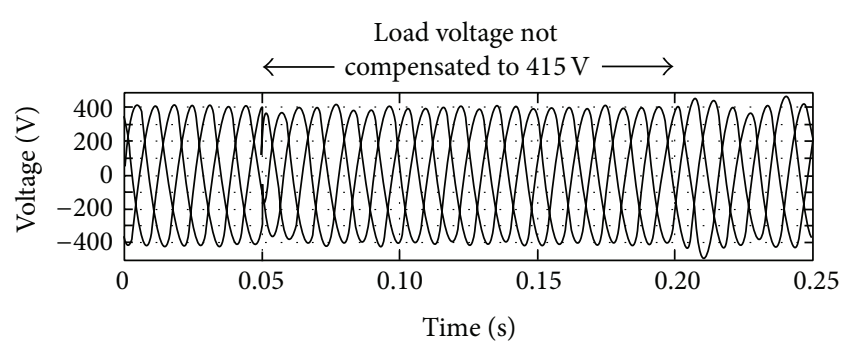

(c)

Figure 23: Sag compensation.

\section{Simulation Results}

A 3-phase, $415 \mathrm{~V}, 50 \mathrm{HZ}$ supply line can be connected to more than one load, that is, due to addition of load or due to fault occurrence on the distribution side, voltage gets distorted; this can be mitigated with the help of DVR. The fuel cell based DVR is simulated with the help of three controllers for sag and swell compensation using Matlab/Simulink platform. In this paper, increase in load or fault occurs at the interval of $0.05 \mathrm{sec}$ to $0.2 \mathrm{sec}$. During that time, DVR is activated and they are deactivated during the rest of the time. In this paper DVR uses energy storage device as super capacitor. By using controllers, when fault occurs or increase in load they provide the error signal for the pulse generator which produces the pulses for the $z$ source inverter which injects the three-phase output voltage into the distribution line via injection transformer. Figures 6, 7, 8, 9, 10, and 11 show the Simulink model for sag, swell, and fault compensation.

\subsection{PI Controller}

Case 1. Case 1 is as follows: compensation of $40 \%$ three-phase voltage sag (Figure 12) and $10 \%$ three-phase voltage swell (Figure 13), under condition of adding an additional load to 


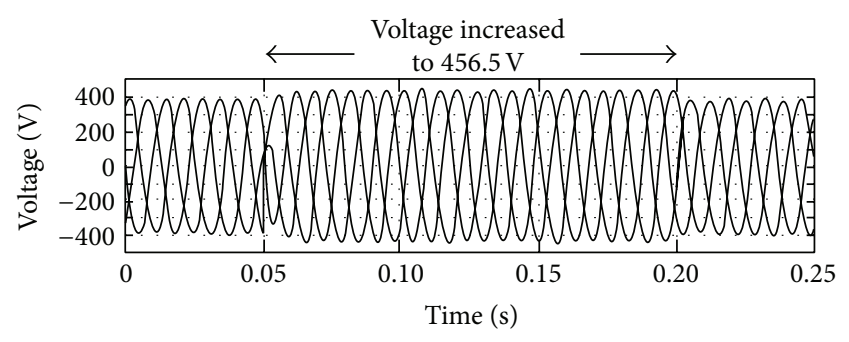

(a)

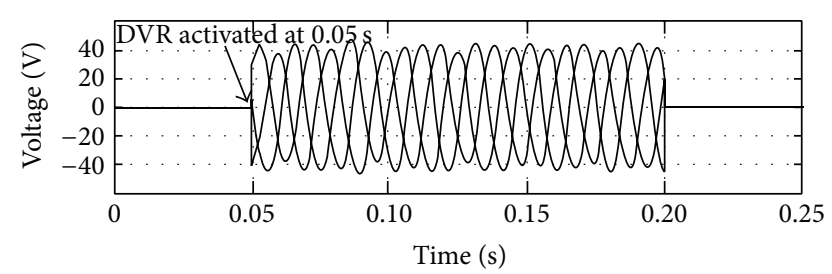

(b)

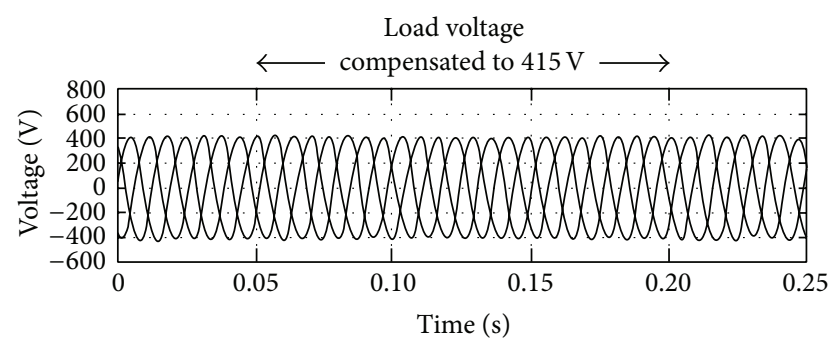

(c)

FIgURE 24: Swell compensation.

existing load/removal of load. The existing load is a linear $R-L$ load $\left(R=250 \Omega, L=30 e^{-5} \mathrm{H}\right)$.

Case 2. Case 2 is as follows: compensation of variable threephase voltage sag under different fault conditions. The load chosen is a linear $R-L$ load $\left(R=500 \Omega, L=30 e^{-3} \mathrm{H}\right)$.

\subsubsection{Case 1}

Sag Compensation. A sudden increase in load occurs at $0.05 \mathrm{~s}$ to $0.2 \mathrm{~s}$; voltage dropped to $249 \mathrm{~V}(40 \% \mathrm{sag})$ from $415 \mathrm{~V}$. The DVR is activated at 0.05 second and injects a voltage of $149 \mathrm{~V}$ up to 0.2 second. The load voltage is not compensated to $415 \mathrm{~V}$.

Swell Compensation (Capacitive Load). A sudden addition of capacitive load at 0.05 second occurred; voltage swelled to $456.5 \mathrm{~V}$ (10\% swell). DVR is activated at 0.05 second and injects negative voltage of $50.5 \mathrm{~V}$ up to 0.2 second. The load voltage is not compensated to $415 \mathrm{~V}$.

Swell Compensation (Removal of Load). A sudden removal of load at 0.05 second causes voltage swell to $456.5 \mathrm{~V}$ (10\% swell). DVR is activated at 0.05 second and injects negative voltage of $64.5 \mathrm{~V}$ to phase $\mathrm{A}, 86.5 \mathrm{~V}$ to phase $\mathrm{B}$, and $74.5 \mathrm{~V}$ to phase C. The load voltage is not compensated to $415 \mathrm{~V}$ (Figure 14).

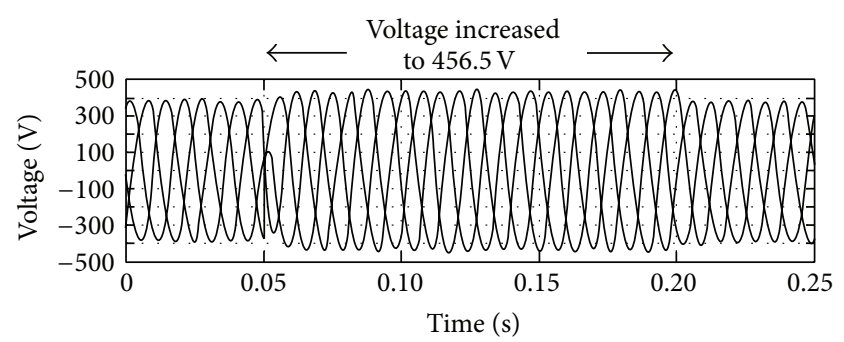

(a)

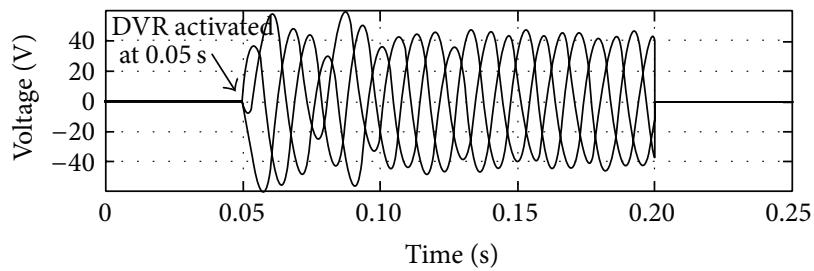

(b)

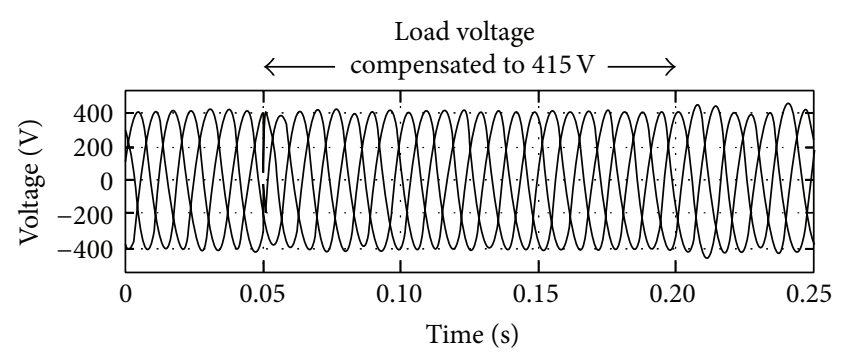

(c)

FIGURE 25: Swell compensation (removal of load).

\subsubsection{Case 2}

Three-Phase Fault Compensation. A three-phase fault occurred at $0.05 \mathrm{~s}$ and the voltage in all the three phases are dipped to $210 \mathrm{~V}$. DVR is activated at $0.05 \mathrm{~s}$ and it injects a voltage of $190 \mathrm{~V}$ in all the three phases. Load voltage is not compensated to $415 \mathrm{~V}$ (Figure 15).

Line to Line Fault Compensation. A line to line (LL) fault occurred at $0.05 \mathrm{~s}$; the voltage in phase A dipped to $340 \mathrm{~V}$ and the voltage in phase B dipped to $330 \mathrm{~V}$. DVR is activated at $0.05 \mathrm{~s}$ and it injects a compensating voltage of $65 \mathrm{~V}$ to phase $\mathrm{A}$ and $70 \mathrm{~V}$ to phase $\mathrm{B}$. Load voltage is not compensated to $415 \mathrm{~V}$ (Figure 16).

Single Line to Ground Fault Compensation. A single line to ground (LG) fault occurred at $0.05 \mathrm{~s}$; voltage dipped to $225 \mathrm{~V}$ from $415 \mathrm{~V}$ in phase $\mathrm{A}$. The compensating voltage is provided by a fuel cell for that phase. DVR is activated at $0.05 \mathrm{~s}$ and the load voltage is not compensated to $415 \mathrm{~V}$ (Figure 17).

Double Line to Ground Fault Compensation. A double line to ground (LLG) fault occurred at $0.05 \mathrm{~s}$ and the voltage in phase A dipped to $310 \mathrm{~V}$ and the voltage in phase $\mathrm{B}$ dipped to $320 \mathrm{~V}$. DVR is activated at $0.05 \mathrm{~s}$ and it injects a compensating voltage of $95 \mathrm{~V}$ in phase $\mathrm{A}$ and a voltage of $85 \mathrm{~V}$ in phase $\mathrm{B}$. Load voltage is not compensated to $415 \mathrm{~V}$ (Figure 18). 


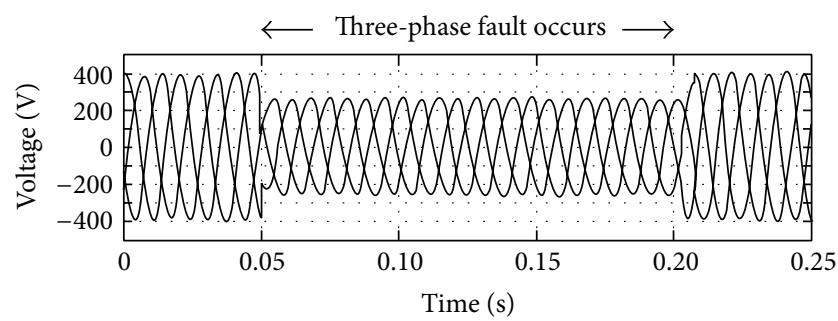

(a)

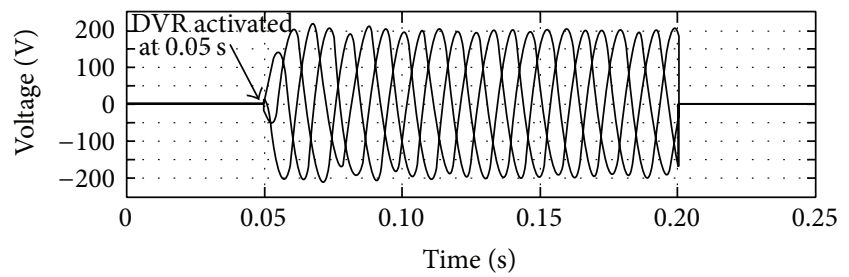

(b)

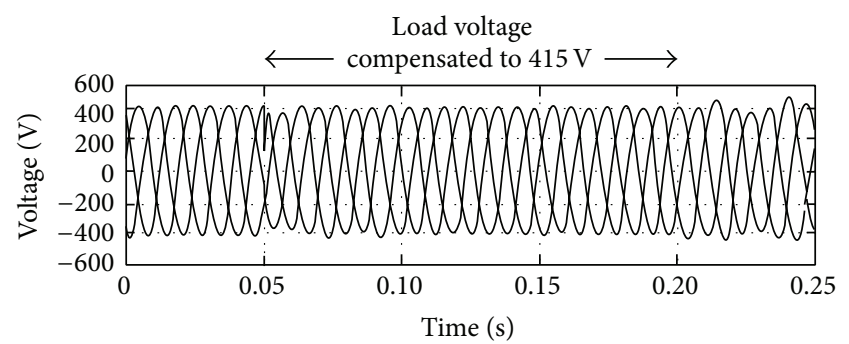

(c)

Figure 26: A three-phase fault sag compensation (fuzzy).

\subsection{Synchronous Reference Frame Method}

Case 1. Case 1 is as follows: compensation of $40 \%$ three-phase voltage sag and $10 \%$ three-phase voltage swell, under condition of adding an additional load to existing load/removal of load. The existing load is a linear $R-L$ load $(R=250 \Omega, L=$ $\left.30 e^{-5} \mathrm{H}\right)$.

Case 2. Case is as follows: compensation of variable threephase voltage sag under different fault conditions. The load chosen is a linear $R-L$ load $\left(R=500 \Omega, L=30 e^{-5} \mathrm{H}\right)$.

\subsubsection{Case 1}

Sag Compensation. Additional load is added during the period of $0.05 \mathrm{~s}$ to $0.2 \mathrm{~s}$ so sag occurs and the voltage in all 3 phases drops to $249 \mathrm{~V}$. DVR is activated at $0.05 \mathrm{~s}$ and it provides the compensating voltage of $141 \mathrm{~V}$ to phase $\mathrm{A}, 137 \mathrm{~V}$ to phase $\mathrm{B}$, and $120 \mathrm{~V}$ to phase $\mathrm{C}$ (Table 1 ). The load voltage is not compensated to $415 \mathrm{~V}$ (Figure 19).

Swell Compensation (Capacitive Load). Additional capacitive load is added during the period of $0.05 \mathrm{~s}$ to $0.2 \mathrm{~s}$ so swell occurs and the voltage increases to $456.5 \mathrm{~V}$. DVR is activated at $0.05 \mathrm{~s}$ and it provides the compensating voltage of $51.5 \mathrm{~V}$ to

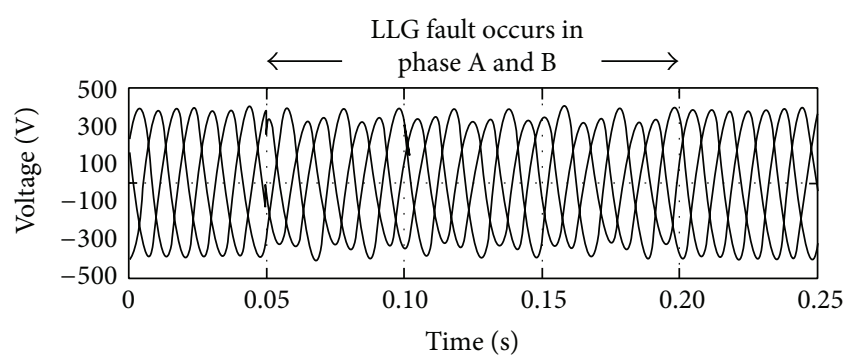

(a)

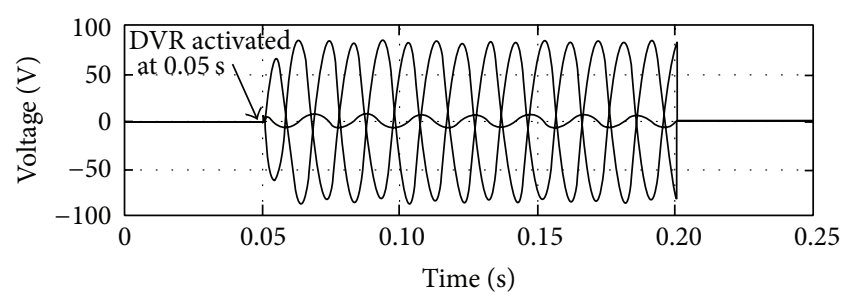

(b)

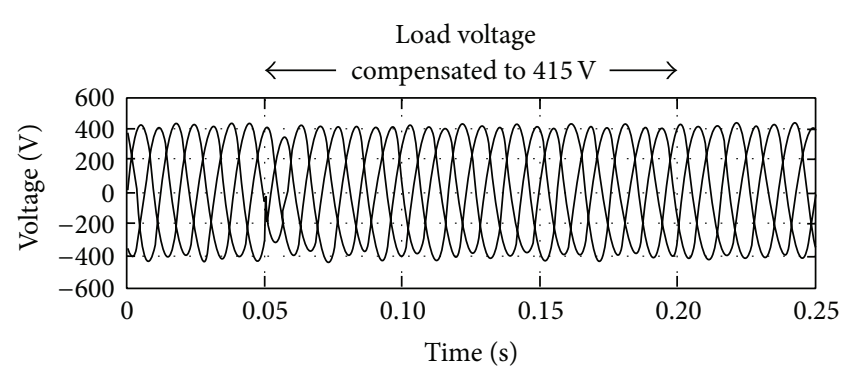

(c)

FIgURE 27: A line to line fault sag compensation.

phase $\mathrm{A}, 76.5 \mathrm{~V}$ to phase $\mathrm{B}$, and $66.5 \mathrm{~V}$ to phase $\mathrm{C}$ (Table 2). The load voltage is not compensated to $415 \mathrm{~V}$ (Figure 20).

Swell Compensation (Removal of Load). A sudden removal of load at 0.05 second causes voltage swell to $456.5 \mathrm{~V}$ (10\% swell). DVR is activated at 0.05 second and injects negative voltage of $53.5 \mathrm{~V}$ to phase $\mathrm{A}, 81.5 \mathrm{~V}$ to phase $\mathrm{B}$, and $66.5 \mathrm{~V}$ to phase $\mathrm{C}$. The load voltage is not compensated to $415 \mathrm{~V}$ (Figure 21).

Double Line to Ground Fault Compensation. A double line to ground fault occurs during the period of $0.05 \mathrm{~s}$ to $0.2 \mathrm{~s}$ so sag occurs and the voltage drops to $410 \mathrm{~V}$ in phase A, $310 \mathrm{~V}$ in phase $B$, and $320 \mathrm{~V}$ in phase C. DVR is activated at $0.05 \mathrm{~s}$ and it provides the compensating voltage of $5 \mathrm{~V}$ to phase $\mathrm{A}$, $101 \mathrm{~V}$ to phase $\mathrm{B}$, and $93 \mathrm{~V}$ to phase $\mathrm{C}$. The load voltage is not compensated to $415 \mathrm{~V}$ (Figure 22).

\subsection{Fuzzy Algorithm}

Case 1. Case 1 is as follows: compensation of $40 \%$ three-phase voltage sag and $10 \%$ three-phase voltage swell, under condition of adding an additional load to existing load/removal of load. The existing load is a linear $R-L$ load $(R=250 \Omega, L=$ $\left.30 e^{-5} \mathrm{H}\right)$. 
TABLE 1: Comparison of distorted voltage, injected voltage, and load voltage for different controllers (sag compensation).

\begin{tabular}{lccccccccc}
\hline \multirow{2}{*}{ Controllers } & \multicolumn{3}{c}{ Distorted voltage (volts) } & \multicolumn{3}{c}{ Injected voltage (volts) } & \multicolumn{3}{c}{ Load voltage (volts) } \\
& Phase A & Phase B & Phase C & Phase A & Phase B & Phase C & Phase A & Phase B & Phase C \\
\hline PI & 249 & 249 & 249 & 141 & 137 & 120 & 390 & 386 \\
SRF & 249 & 249 & 249 & 146 & 143 & 126 & 395 & 392 \\
Fuzzy & 249 & 249 & 249 & 166 & 166 & 166 & 415 & 415 & 415 \\
\hline
\end{tabular}

TABLE 2: Comparison of distorted voltage, injected voltage, and load voltage for different controllers (swell compensation).

\begin{tabular}{lcccccccc}
\hline \multirow{2}{*}{ Controllers } & \multicolumn{3}{c}{ Distorted voltage (volts) } & \multicolumn{3}{c}{ Injected voltage (volts) } & \multicolumn{3}{c}{ Load voltage (volts) } \\
& Phase A & Phase B & Phase C & Phase A & Phase B & Phase C & Phase A & Phase B \\
\hline PI & 456.5 & 456.5 & 456.5 & 64.5 & 86.5 & 74.5 & 392 & 370 \\
SRF & 456.5 & 456.5 & 456.5 & 53.5 & 81.5 & 66.5 & 403 & 382 \\
Fuzzy & 456.5 & 456.5 & 456.5 & 41.5 & 41.5 & 41.5 & 415 & 415 \\
\hline
\end{tabular}

Case 2. Case 2 is as follows: compensation of variable threephase voltage sag under different fault conditions. The load chosen is a linear $R-L$ load $\left(R=500 \Omega, L=30 e^{-3} \mathrm{H}\right)$.

\subsubsection{Case 1}

Sag Compensation. Additional load is added during the period of $0.05 \mathrm{~s}$ to $0.2 \mathrm{~s}$ so sag occurs and the voltage drops to $249 \mathrm{~V}$. DVR is activated at $0.05 \mathrm{~s}$ and it provides the compensating voltage of $166 \mathrm{~V}$. The load voltage is compensated to $415 \mathrm{~V}$ (Figure 23).

Swell Compensation (Capacitive Load). Additional capacitive load is added during the period of $0.05 \mathrm{~s}$ to $0.2 \mathrm{~s}$ so swell occurs and the voltage increases to $456.5 \mathrm{~V}$. DVR is activated at $0.05 \mathrm{~s}$ and it provides the compensating voltage of $41.5 \mathrm{~V}$. The load voltage is compensated to $415 \mathrm{~V}$ (Figure 24).

Swell Compensation (Removal of Load). A sudden removal of load at 0.05 second causes voltage swell to $456.5 \mathrm{~V}$ (10\% swell). DVR is activated at 0.05 second and injects negative voltage of $41.5 \mathrm{~V}$ up to 0.2 second. The load voltage is compensated to $415 \mathrm{~V}$ (Figure 25).

\subsubsection{Case 2}

Fault Compensation: Three-Phase Fault Compensation. A three-phase fault occurs during the period of $0.05 \mathrm{~s}$ to $0.2 \mathrm{~s}$ so sag occurs and the voltage drops to $210 \mathrm{~V}$ in all the phases. DVR is activated at $0.05 \mathrm{~s}$ and it provides the compensating voltage of $215 \mathrm{~V}$ to phase $\mathrm{A}, 215 \mathrm{~V}$ to phase $\mathrm{B}$, and $215 \mathrm{~V}$ to phase $\mathrm{C}$ (Table 3 ). The load voltage is compensated to $415 \mathrm{~V}$ (Figure 26).

Line to Line Fault Compensation. A line to line fault occurs during the period of $0.05 \mathrm{~s}$ to $0.2 \mathrm{~s}$ so sag occurs and the voltage drops to $413 \mathrm{~V}$ in phase $\mathrm{A}, 340 \mathrm{~V}$ in phase $\mathrm{B}$, and $330 \mathrm{~V}$ in Phase C. DVR is activated at $0.05 \mathrm{~s}$ and it provides the

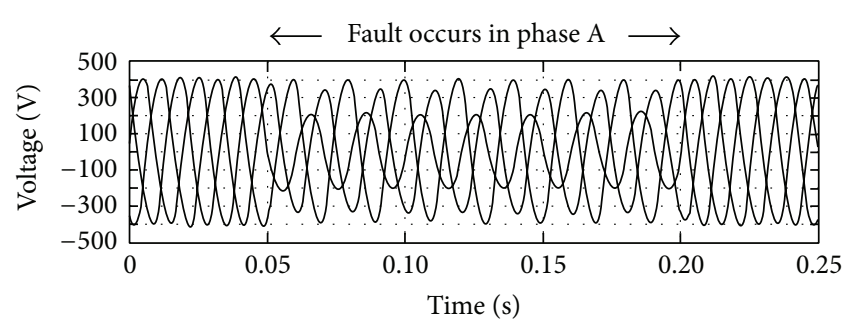

(a)

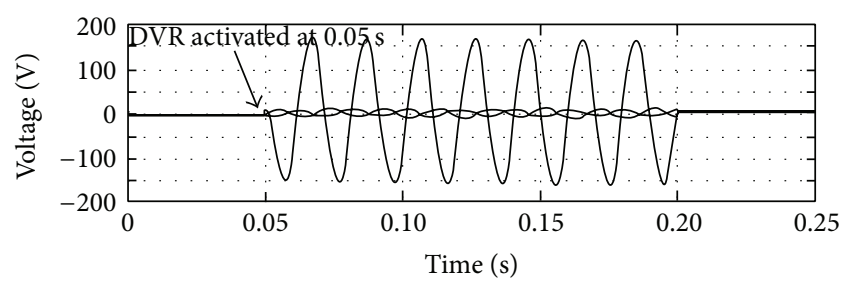

(b)

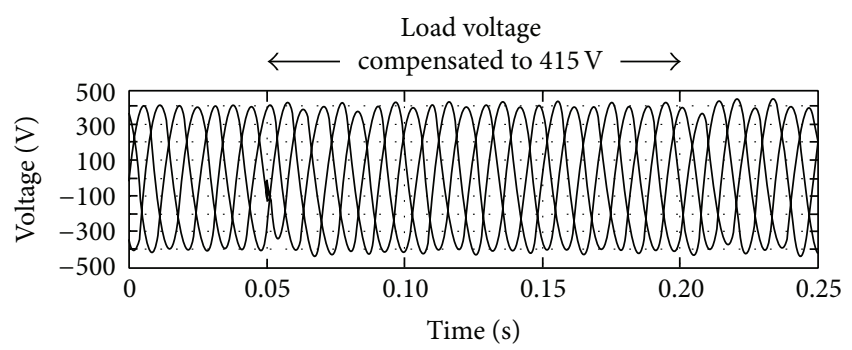

(c)

FIGURE 28: A line to ground fault sag compensation (fuzzy).

compensating voltage of $2 \mathrm{~V}$ to phase $\mathrm{A}, 63 \mathrm{~V}$ to phase $\mathrm{B}$, and $72 \mathrm{~V}$ to phase C. The load voltage is not compensated to $415 \mathrm{~V}$ (Figure 27).

Line to Ground Fault Compensation. A line to line fault occurs during the period of $0.05 \mathrm{~s}$ to $0.2 \mathrm{~s}$ so sag occurs and 
TABLE 3: Comparison of distorted voltage, injected voltage, and load voltage for different controllers (fault compensation).

\begin{tabular}{|c|c|c|c|c|c|c|c|c|c|c|}
\hline \multirow{2}{*}{ Controllers } & \multirow{2}{*}{ Faults } & \multicolumn{3}{|c|}{ Distorted voltage (volts) } & \multicolumn{3}{|c|}{ Injected voltage (volts) } & \multicolumn{3}{|c|}{ Load voltage (volts) } \\
\hline & & Phase A & Phase B & Phase C & Phase A & Phase B & Phase C & Phase A & Phase B & Phase C \\
\hline \multirow{4}{*}{ PI } & LG & 225 & 415 & 390 & 85 & 0 & 23 & 310 & 415 & 413 \\
\hline & $\mathrm{LL}$ & 413 & 340 & 330 & 2 & 63 & 72 & 415 & 403 & 402 \\
\hline & LLG & 410 & 310 & 320 & 5 & 90 & 70 & 415 & 400 & 390 \\
\hline & 3 phase & 210 & 210 & 210 & 215 & 205 & 170 & 425 & 405 & 380 \\
\hline \multirow{4}{*}{ SRF } & LG & 225 & 415 & 390 & 188 & 0 & 20 & 413 & 415 & 410 \\
\hline & $\mathrm{LL}$ & 413 & 340 & 330 & 2 & 72 & 80 & 415 & 412 & 410 \\
\hline & LLG & 410 & 310 & 320 & 5 & 101 & 93 & 415 & 411 & 413 \\
\hline & 3 phase & 210 & 210 & 210 & 215 & 210 & 170 & 425 & 420 & 380 \\
\hline \multirow{4}{*}{ Fuzzy } & LG & 225 & 415 & 390 & 190 & 0 & 25 & 415 & 415 & 415 \\
\hline & $\mathrm{LL}$ & 413 & 340 & 330 & 2 & 75 & 85 & 415 & 415 & 415 \\
\hline & LLG & 410 & 310 & 320 & 5 & 105 & 95 & 415 & 415 & 415 \\
\hline & 3 phase & 210 & 210 & 210 & 215 & 215 & 215 & 415 & 415 & 415 \\
\hline
\end{tabular}

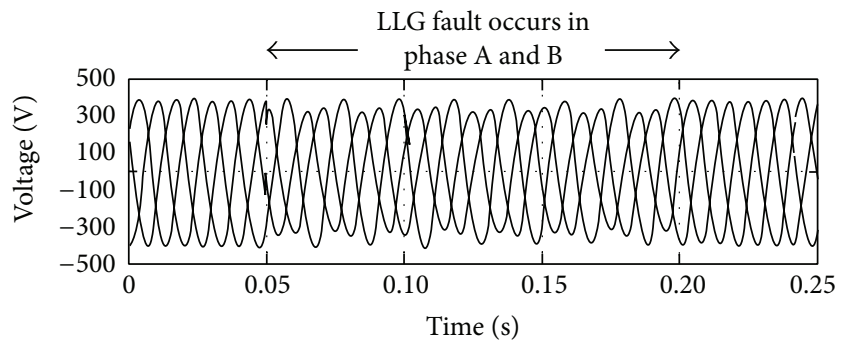

(a)

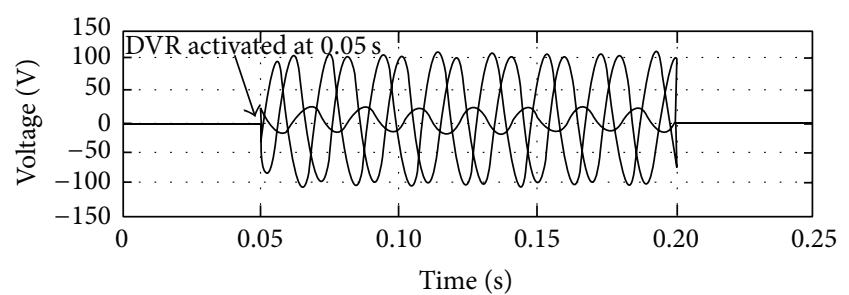

(b)

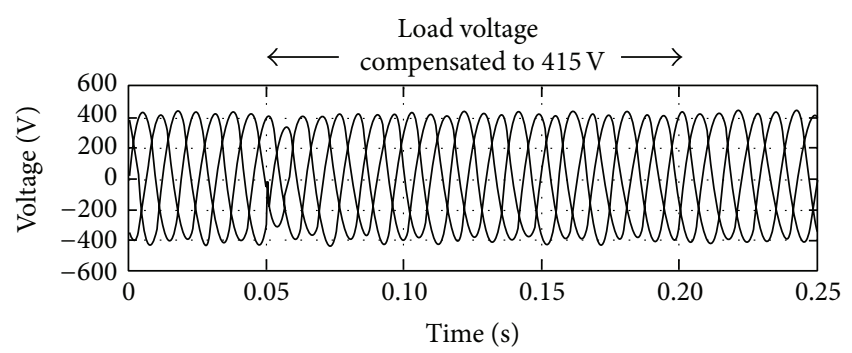

(c)

Figure 29: Double line to ground fault sag compensation.

the voltage drops to $413 \mathrm{~V}$ in phase $\mathrm{A}, 340 \mathrm{~V}$ in phase $\mathrm{B}$, and $330 \mathrm{~V}$ in phase C. DVR is activated at $0.05 \mathrm{~s}$ and it provides the compensating voltage of $2 \mathrm{~V}$ to phase $\mathrm{A}, 72 \mathrm{~V}$ to phase $\mathrm{B}$, and $85 \mathrm{~V}$ to phase $\mathrm{C}$. The load voltage is compensated to $415 \mathrm{~V}$ (Figure 28).

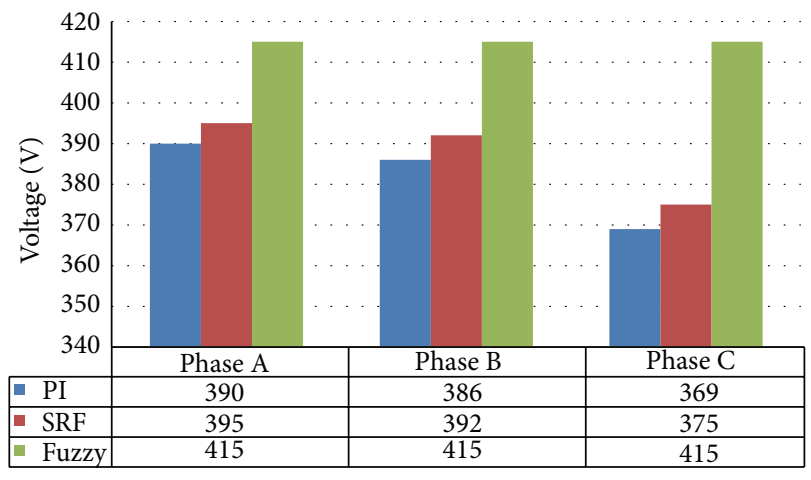

FIgURE 30: Comparative analysis for sag compensation.

Double Line to Ground Fault Compensation. A double line to ground fault occurs during the period of $0.05 \mathrm{~s}$ to $0.2 \mathrm{~s}$ so sag occurs and the voltage drops to $410 \mathrm{~V}$ in phase $\mathrm{A}, 310 \mathrm{~V}$ in phase $\mathrm{B}$, and $320 \mathrm{~V}$ in phase $\mathrm{C}$. DVR is activated at $0.05 \mathrm{~s}$ and it provides the compensating voltage of $5 \mathrm{~V}$ to phase $\mathrm{A}, 105 \mathrm{~V}$ to phase $\mathrm{B}$, and $95 \mathrm{~V}$ to phase $\mathrm{C}$. The load voltage is compensated to $415 \mathrm{~V}$ (Figure 29).

The comparative analysis of various control methods for sag compensation is shown in Figure 30.

(i) Additional load is added during the period of $0.05 \mathrm{sec}$ to $0.2 \mathrm{sec}$, so sag occurs and the voltage drops.

(ii) DVR is activated at $0.05 \mathrm{sec}$ and it provides the compensating voltage.

(iii) From the three control methods, it is evident that the fuzzy is superior to the other methods.

(iv) With the fuzzy controller, voltage restoration is maximum.

The comparative analysis of various control methods for swell compensation is shown in Figure 31. 


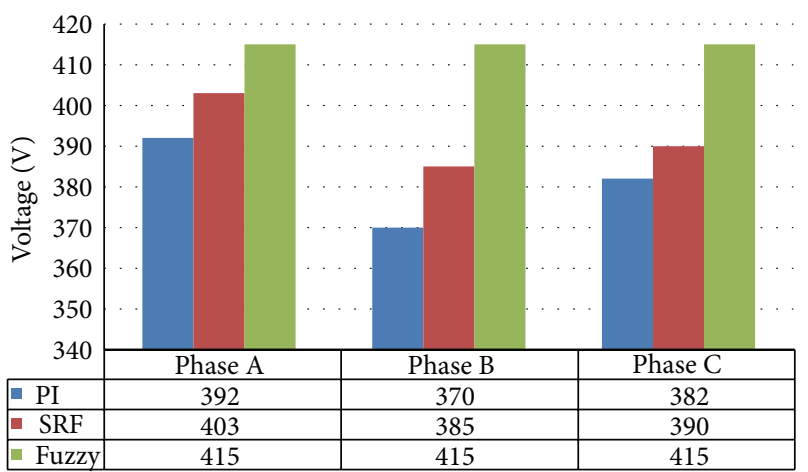

FIGURE 31: Comparative analysis for swell compensation (sudden removal of load).

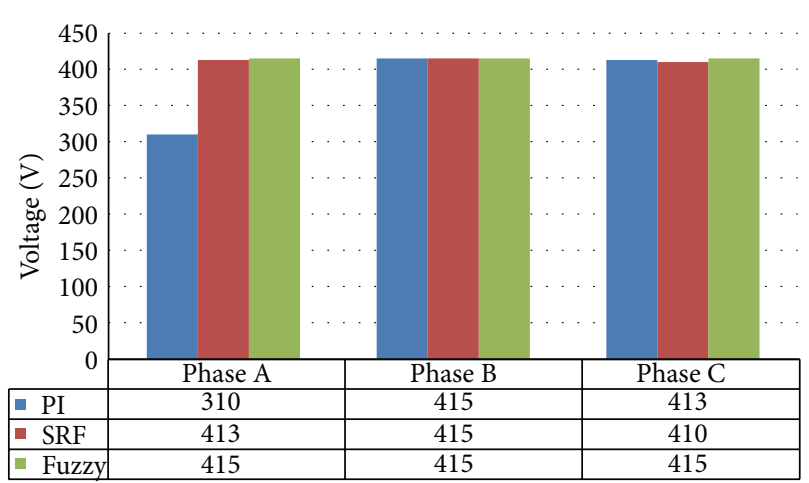

FIGURE 32: Comparative analysis for LG fault sag compensation.

(i) A sudden removal of load at $0.05 \mathrm{sec}$ causes voltage swell (10\% swell).

(ii) DVR is activated at $0.05 \mathrm{sec}$ and injects negative voltage up to $0.2 \mathrm{sec}$.

(iii) From the three control methods, it is evident that the fuzzy is superior to the other methods.

(iv) With the fuzzy controller, voltage restoration is maximum.

The comparative analysis of various control methods for sag compensation (LG fault) is shown in Figure 32.

(i) Single line to ground fault occurs during the period of $0.05 \mathrm{sec}$ to $0.2 \mathrm{sec}$, so sag occurs and the voltage drops in phase $\mathrm{A}$ and phase $\mathrm{C}$.

(ii) DVR is activated at $0.05 \mathrm{sec}$ and it provides the compensating voltage.

(iii) From the three control methods, it is evident that the fuzzy is superior to the other methods.

(iv) With the fuzzy controller, voltage restoration is maximum.

The comparative analysis of various control methods for sag compensation (LL fault) is shown in Figure 33.

(i) A line to line fault occurs during the period of $0.05 \mathrm{sec}$ to $0.2 \mathrm{sec}$, so sag occurs and the voltage drops in phase $A$, phase $B$, and phase $C$.

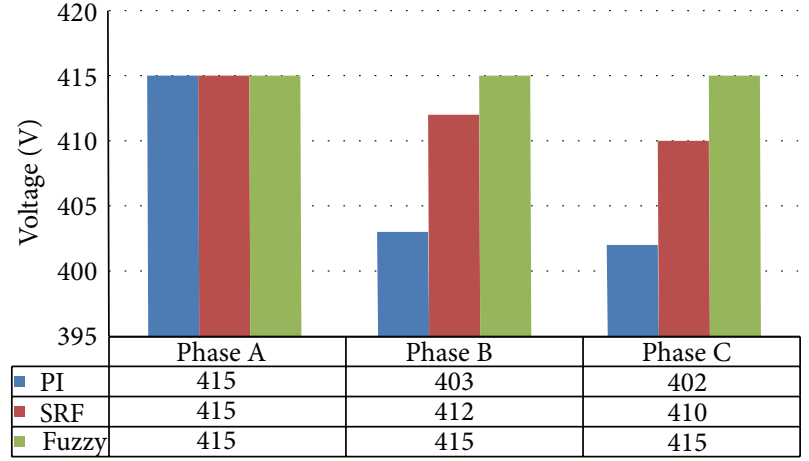

FIGURE 33: Comparative analysis for LL fault sag compensation.

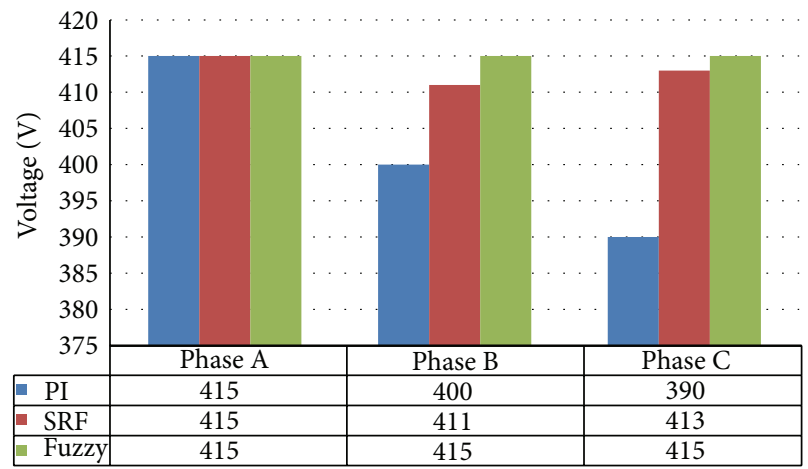

Figure 34: Comparative analysis for LLG fault sag compensation.

(ii) DVR is activated at $0.05 \mathrm{sec}$ and it provides the compensating voltage.

(iii) From the three control methods, it is evident that the fuzzy is superior to the other methods.

(iv) With the fuzzy controller, voltage restoration is maximum.

The comparative analysis of various control methods for sag compensation (LLG fault) is shown in Figure 34.

(i) A double line to ground fault occurs during the period of $0.05 \mathrm{sec}$ to $0.2 \mathrm{sec}$, so sag occurs and the voltage drops in phase $A$, phase $B$, and phase $C$.

(ii) DVR is activated at $0.05 \mathrm{sec}$ and it provides the compensating voltage.

(iii) From the three control methods, it is evident that the fuzzy is superior to the other methods.

(iv) With the fuzzy controller, voltage restoration is maximum.

The comparative analysis of various control methods for sag compensation (three-phase fault) is shown in Figure 35.

(i) A three-phase fault occurs during the period of $0.05 \mathrm{sec}$ to $0.2 \mathrm{sec}$, so sag occurs and the voltage drops in all the phases.

(ii) DVR is activated at $0.05 \mathrm{sec}$ and it provides the compensating voltage. 


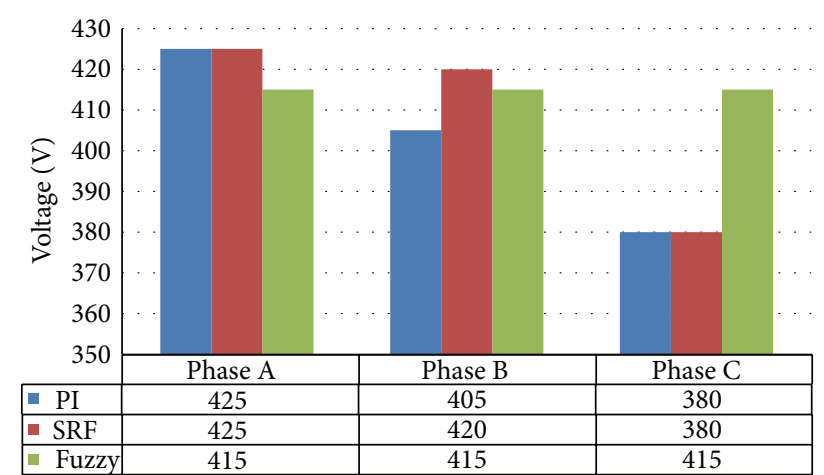

FIGURE 35: Comparative analysis for three-phase fault sag compensation.

(iii) From the three control methods, it is evident that the fuzzy is superior to the other methods.

(iv) With the fuzzy controller, voltage restoration is maximum.

\section{Conclusion}

This paper has proposed a DVR with polymer electrolyte membrane (PEM) fuel cell to mitigate the voltage sag and swell. Three different voltage controllers were designed for DVR voltage regulation. PI Controller, SRF controller, and fuzzy logic controller are the three voltage controllers used. After a detailed analysis it is found that fuzzy logic controller is the best. The simulation result shows both the balanced and unbalanced faults sag compensation and the swell compensation for the addition of capacitive load. The simulation results validate the efficiency of the DVR which is able to compensate $40 \%$ voltage sag and $10 \%$ swell. Time domain simulations of the DVR under different conditions have validated the operation of the proposed DVR.

PI controller provides sag compensation of $34 \%$ in phase A, $33 \%$ in phase B, and $28 \%$ in phase C. It provides swell compensation of $16 \%$ in phase A, $20 \%$ in phase $\mathrm{B}$, and $18 \%$ in phase C. A synchronous reference frame controller (SRF) provides sag compensation of $35 \%$ in phase $\mathrm{A}, 34 \%$ in phase $\mathrm{B}$, and $30 \%$ in phase $\mathrm{C}$ and provides swell compensation of $12 \%$ in phase $A, 19 \%$ in phase B, and $16 \%$ in phase C. Fuzzy controller provides sag compensation of $40 \%$ in all phases and swell compensation of $10 \%$ in all phases.

In PI controller, voltage sag caused by LG fault is compensated by $20 \%$ in phase A. Voltage sag caused by LL fault is compensated by $15 \%$ in phase B and $17 \%$ in phase C. Voltage sag caused by LLG fault is compensated by $21 \%$ in phase $B$ and $16 \%$ in phase $C$. Voltage sag caused by three-phase fault is compensated by $51 \%$ in phase A, $49 \%$ in phase B, and $40 \%$ in phase $C$.

In SRF controller, voltage sag caused by LG fault is compensated by $45 \%$ in phase A. Voltage sag caused by LL fault is compensated by $17 \%$ in phase $\mathrm{B}$ and $20 \%$ in phase C. Voltage sag caused by LLG fault is compensated by $24 \%$ in phase B and $22 \%$ in phase C. Voltage sag caused by threephase fault is compensated by $52 \%$ in phase $\mathrm{A}, 48 \%$ in phase $\mathrm{B}$, and $40 \%$ in phase $\mathrm{C}$.

In fuzzy controller, voltage sag caused by LG fault is compensated by $45 \%$ in phase A. Voltage sag caused by LL fault is compensated by $18 \%$ in phase $\mathrm{B}$ and $20 \%$ in phase C. Voltage sag caused by LLG fault is compensated by $25 \%$ in phase $\mathrm{B}$ and $23 \%$ in phase C. Voltage sag caused by threephase fault is compensated by $51 \%$ in all the phases. From above results, it is clear the fuzzy controller is the most efficient in voltage sag and swell compensation.

\section{Appendices}

\section{A. Simulation Parameters}

Nominal frequency: $50 \mathrm{~Hz}$

Three-phase peak amplitude: $415 \mathrm{~V}$

Line resistance: 0.1

Line inductance: $10 e^{-3}$.

Load

Active power: $10 e^{3} \mathrm{~W}$

Resistance: 250

Inductance: $31 e^{-5}$.

\section{B. PI Controller}

\section{B.1. Case 1: Addition of Load}

Sag
Active power: $10 e^{3} \mathrm{~W}$
Inductive reactive power QL: $20 e^{4}$
Capacitive reactive power Qc: 0
Resistance: 87
Inductance: $25 e^{-4}$.

Swell
Active power: $50 e^{3} \mathrm{~W}$
Inductive reactive power: QL 0
Capacitive reactive power: Qc $80 e^{3}$
Resistance: 50.

\section{B.2. Case 2: Sag due to Fault Occurrence}

Single Line to Ground Fault

Fault resistance ron: 20

Ground resistance Rg: 0.001.

Line to Line Fault

Fault resistance ron: 100 . 
Three-Phase Fault

Fault resistance ron: 37

Ground resistance Rg: 20.

Double Line to Ground Fault

Fault resistance ron: 40

Ground resistance Rg: 10.

\section{SRF Controller}

Sag

Active power: $10 e^{3} \mathrm{~W}$

Inductive reactive power QL: $30 e^{4}$

Capacitive reactive power Qc: 0

Resistance: 93

Inductance: $25 e^{-4}$.

Swell

Active power: $50 e^{3} \mathrm{~W}$

Inductive reactive power: $\mathrm{QL} 0$

Capacitive reactive power: Qc $90 e^{3}$

Resistance: 56.

\section{C.1. Case 2: Sag due to Fault Occurrence}

Single Line to Ground Fault

Fault resistance ron: 40

Ground resistance Rg: 0.001.

Line to Line Fault

Fault resistance ron: 110

Three-Phase Fault

Fault resistance ron: 40

Ground resistance Rg: 30.

Double Line to Ground Fault

Fault resistance ron: 40

Ground resistance Rg: 10.

\section{Fuzzy Controller}

D.1. Case 1: Addition of Load

Sag

Active power: $10 e^{3} \mathrm{~W}$

Inductive reactive power QL: $30 e^{4}$

Capacitive reactive power Qc: 0

Resistance: 93
Inductance: $25 e^{-4}$.

Swell

Active power: $50 e^{3} \mathrm{~W}$

Inductive reactive power: QL 0

Capacitive reactive power: Qc $70 e^{3}$

Resistance: 40.

D.2. Case 2: Sag due to Fault Occurrence

Single Line to Ground Fault

Fault resistance ron: 20

Ground resistance Rg: 0.001.

Line to Line Fault

Fault resistance ron: 60 .

Three-Phase Fault

Fault resistance ron: 30

Ground resistance Rg: 10.

Double Line to Ground Fault

Fault resistance ron: 50

Ground resistance Rg: 10.

\section{Conflict of Interests}

The authors declare that there is no conflict of interests regarding the publication of this paper.

\section{References}

[1] A. Ghosh and G. Ledwich, Power Quality Enhancement Using Custom Power Devices, Kluwer Academic Publishers, Boston, Mass, USA, 2002.

[2] C. Sankaran, Power Quality, CRC press, 2001.

[3] R. C. Dugan, S. Santoso, M. F. McGranaghan, and H. W. Beaty, Electrical Power Systems Quality, McGraw Hill Professional, 2012.

[4] T. Jimichi, H. Fujita, and H. Akagi, "Design and experimentation of a dynamic voltage restorer capable of significantly reducing an energy-storage element," IEEE Transactions on Industry Applications, vol. 44, no. 3, pp. 817-825, 2008.

[5] C. Gopinath and R. Ramesh, "Dynamic voltage restorer using ultra storage capacitor," in Proceedings of the International Conference on Sustainable Energy and Intelligent Systems (SEISCON '11), pp. 69-74, July 2011.

[6] A. M. Hava and N. O. Cetin, "A generalized scalar PWM approach with easy implementation features for three-phase, three-wire voltage-source inverters," IEEE Transactions on Power Electronics, vol. 26, no. 5, pp. 1385-1395, 2011.

[7] C. E. Thenmozhi, C. Gopinath, and R. Ramesh, "A novel method for voltage sag/swell compensation using Dynamic Voltage Restorer," in Proceedings of the IEEE International Conference on Advances in Engineering, Science and Management (ICAESM '12), pp. 333-338, 2012. 
[8] A. Teke, K. Bayindir, and M. Tümay, "Fast sag/swell detection method for fuzzy logic controlled dynamic voltage restorer," IET Generation, Transmission and Distribution, vol. 4, no. 1, pp. 1-12, 2010.

[9] F. Babir, PEM Fuel Cells, Academic Press, 2nd edition, 2012.

[10] S. Jain, J. Jiang, X. Huang, and S. Stevandic, "Modeling of fuel cell based power supply system for grid interface," IEEE Transactions on Industry Applications, vol. 48, no. 4, pp. 11421153, 2012.

[11] J. Rabi and R. Arumugam, "Harmonics study and comparison of Z-source inverter," The American Journal of Applied Sciences, vol. 2, no. 10, pp. 1418-1426, 2010.

[12] F. Z. Peng, "Z-source inverter," IEEE Transactions on Industry Applications, vol. 39, no. 2, pp. 504-510, 2003.

[13] P. Thounthong, A. Luksanasakul, P. Koseeyaporn, and B. Davat, "Intelligent model-based control of a standalone Photovoltaic/Fuel cell power plant with supercapacitor energy storage," IEEE Transactions on Sustainable Energy, vol. 4, no. 1, pp. 240-249, 2013.

[14] Y. Cheng, J. Van Mierlo, P. Van Den Bossche, and P. Lataire, "Using super capacitor based energy storage to improve power quality in distributed power generation," in Proceedings of the 12th International Power Electronics and Motion Control Conference (EPE-PEMC '06), vol. 4, pp. 537-543, September 2006.

[15] P. Drábek and L. Streit, "The energy storage system based on the supercapacitors," in Proceedings of the IEEE International Symposium on Industrial Electronics (ISIE '11), pp. 1672-1676, June 2011.

[16] S. Luri, I. Etxeberria-Otadui, A. Rujas, E. Bilbao, and A. González, "Design of a supercapacitor based storage system for improved elevator applications," in Proceedings of the 2nd IEEE Energy Conversion Congress and Exposition (ECCE '10), pp. 4534-4539, September 2010. 


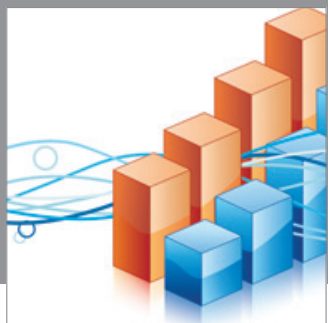

Advances in

Operations Research

mansans

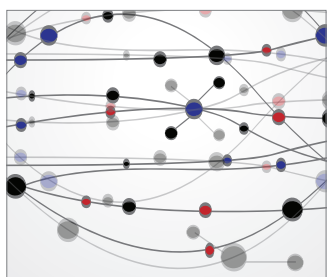

The Scientific World Journal
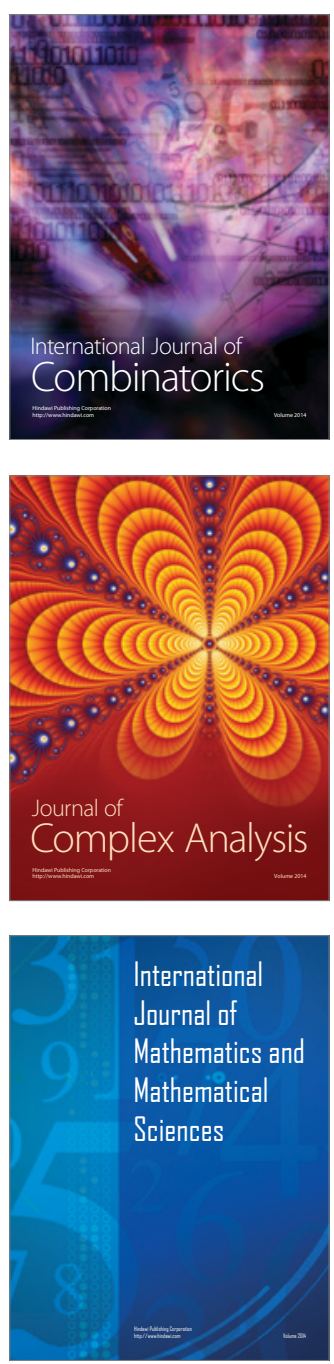
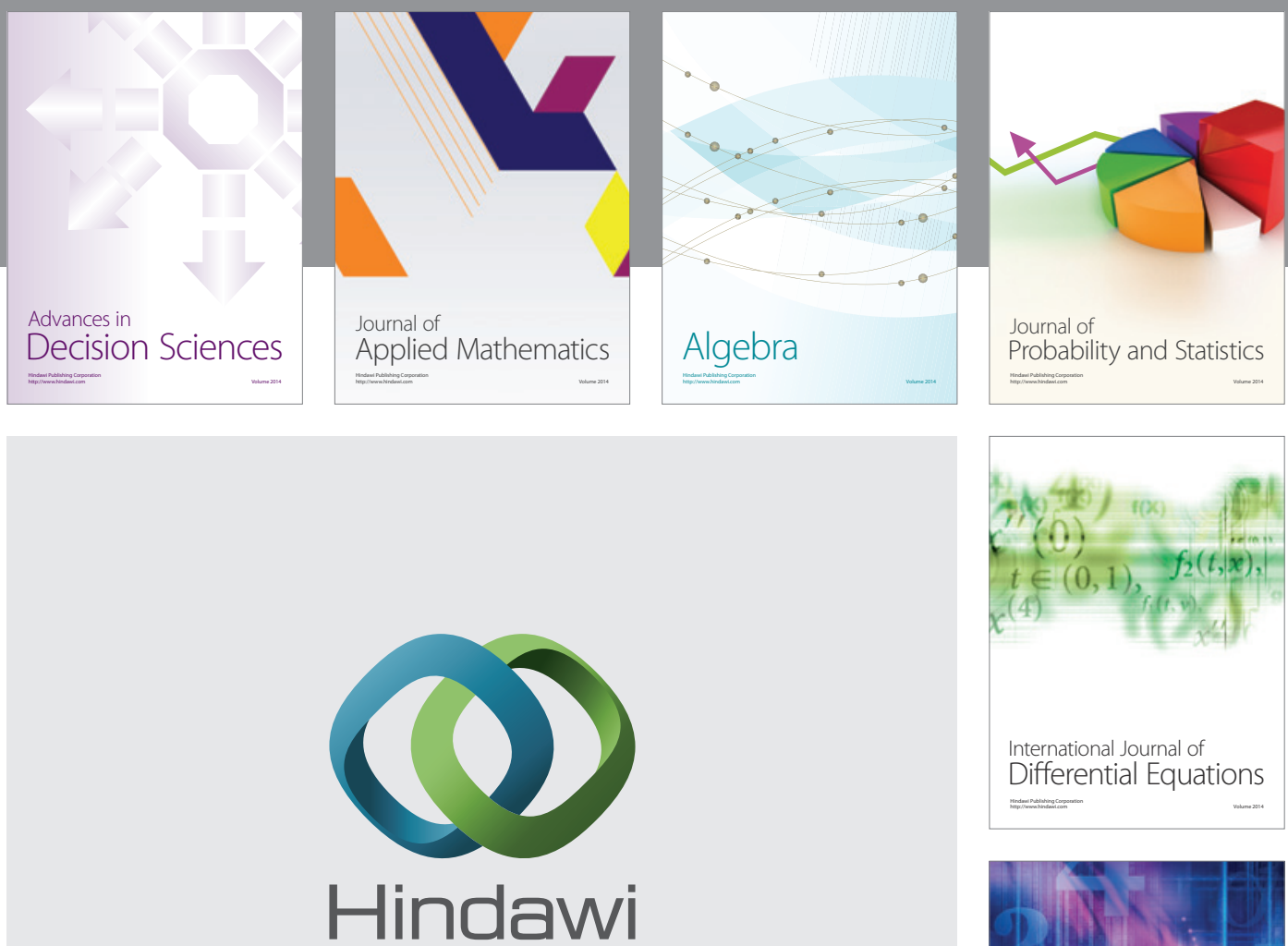

Submit your manuscripts at http://www.hindawi.com
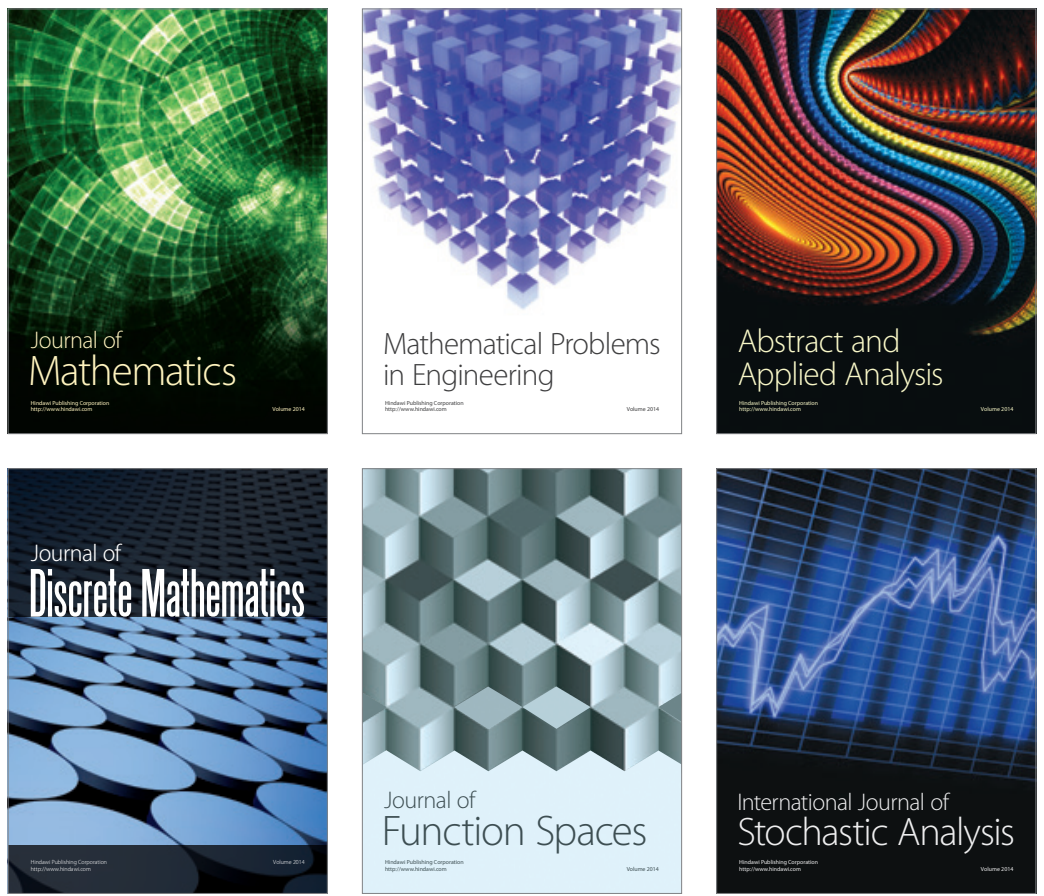

Journal of

Function Spaces

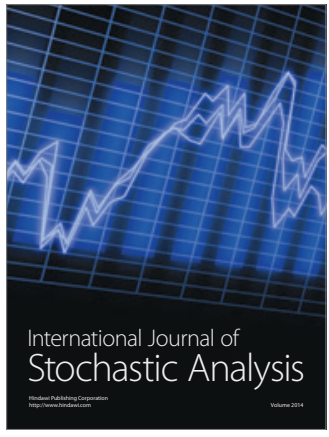

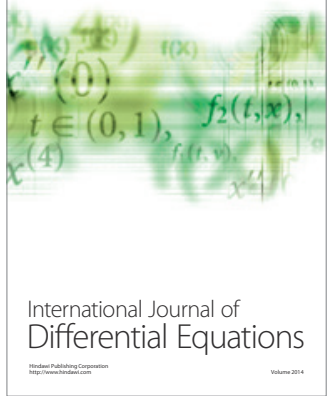
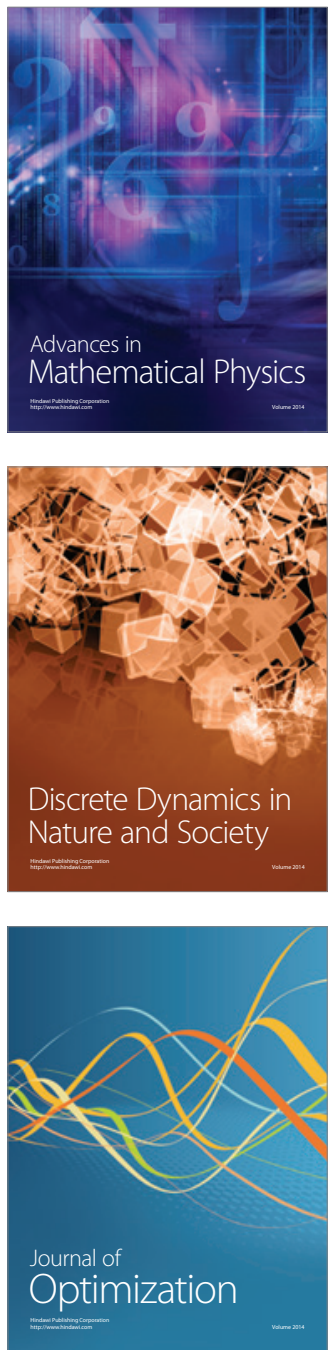